Original Research

\title{
Contamination, Distribution and Health Risk Assessment of Risk Elements in Topsoil for Amusement Parks in Xi'an, China
}

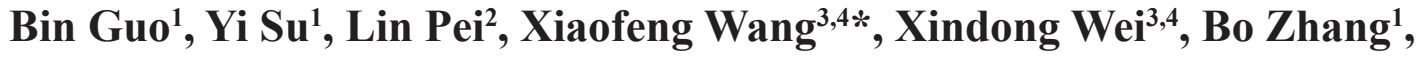 \\ Dingming Zhang', Xiaoxia Wang ${ }^{1}$ \\ ${ }^{1}$ College of Geomatics, Xi' an University of Science and Technology, Xi'an, China \\ ${ }^{2}$ School of Public Health, Xi' an JiaoTong University, Xi'an, China \\ ${ }^{3}$ Shaanxi Key Laboratory of Land Consolidation, Xi'an, China \\ ${ }^{4}$ School of Earth Science and Resources, Chang'an University, Xi'an, China
}

Received: 13 March 2020

Accepted: 5 June 2020

\begin{abstract}
The index of geo-accumulation $\left(\mathrm{I}_{\text {geo }}\right.$ ) and the pollution load index (PLI) were used to assess the pollution level and the U.S. Environmental Protection Agency (EPA) health risk model was implemented to determine the health risk for children. Besides, a geographic information system (GIS) was utilized to map the distribution characteristics of risk elements contents. The results showed that: (1) the mean content of Mn was the highest in each park. Besides, the mean content of all risk elements except As exceeded the background value of Shaanxi in each park. (2) The $I_{\text {geo }}$ of Co was obviously higher than other elements in each park and the highest (4.07) content occurred in the Xing Qing Park (XQP). The pollution condition of the Urban Sports Park (USP) was the most serious among the four parks. (3) The children were more susceptible to risk elements pollution through oral intake. (4) The hazard indices $(\mathrm{HI})$ of non-carcinogenic risk $(\mathrm{NCR})$ were within the safe range $(\mathrm{HI}=1)$ and the carcinogenic risks $(\mathrm{CR})$ of $\mathrm{Cr}, \mathrm{Ni}$, As and $\mathrm{Co}$ for children were within the receivable range in each park.
\end{abstract}

Keywords: topsoil, toxic elements, spatial distribution, pollution level, XRF

\section{Introduction}

Soil is suffering from serious risk elements contamination globally for the past few decades, which has become a great concern topic [1-3]. Soil pollution is particularly serious in China [4]. According to the report released by the global soil pollution symposium in 2018,

*e-mail: XiaoFeng_Wang2@163.com
$16 \%$ of soil and $19 \%$ of agricultural soil in china were regarded as contaminated [5]. The rapid development of urbanization, industrialization and rural intensification have led to the massive emission of toxic risk elements and pollutants [6, 7]. What's more, soil resources are facing unreasonable exploitation and utilization, such as overuse of chemical fertilizers and pesticides, unreasonable treatment of industrial gas and waste water, which result in severe environmental pollution [8-10]. Soil risk elements are difficult to degrade and 
can migrate to plants and human bodies through food chains and water supply systems, which cause direct or indirect harm to food safety and human health [11-13]. In recent years, pollution load index (PLI), ecological risk index (ERI) and geo-accumulation index $\left(\mathrm{I}_{\text {geo }}\right)$ were widely utilized to evaluate the pollution level of risk elements all over the world [14-17]. Meanwhile, hazard quotient (HQ), average daily exposure dose (ADD) and hazard index (HI) developed by the US EPA had been widely used to determine the CR and NCR of human health $[18,19]$.

Due to the high density and continued anthropogenic activities in urban areas, the pollution level of risk elements in urban areas are significantly higher than in rural areas [20]. Although existing studies of risk elements paid high attention to industrial lands, suburbs and surrounding roads, campuses, reservoirs, and playgrounds in urban areas [21-26] and many types of researches have been implemented on risk elements content, spatial distribution, contamination level, source identification, health risk in past decades [27-31], some specific and potentially vital exposure locations such as children's amusement parks were neglected. In China, amusement parks are the main recreational places for children. It's probably becoming accumulated sites of potential risk elements for amusement parks exposure to the external environment of urban chronically. Furthermore, children are more susceptible to risk elements pollution than adults. Children can ingest risk elements through using hands or mouth when they contacted soil or inhaled polluted particulate matter from environmental air [32, 33], which might cause adverse cardiovascular and respiratory health risks in the long term [34]. Xi'an, a very popular international tourist destination and national central city, is in the northwest China. The speeding of industrialization and urbanization are rapid in the past decades. In Xi'an, environmental pollution is becoming more and more serious, and the environment has been affecting by the increase of vehicles, continuous construction, and the emissions of industrial [35]. Various studies had been reported to analyze the situation of risk elements pollution [36-39]. Previous studies had shown that urban topsoil and dust existed risk elements pollution in Xi'an [40-42]. For example, risk elements from the urban topsoil were investigated by some scholars, and they found that soil was polluted by natural and anthropogenic factors [43]. Risk elements in street dust of Xi'an were measured in recent years, and the results showed that fossil fuels and construction activities could lead to risk elements pollution [44, 45]. Besides, some studies also focused on risk elements pollution on roads, campuses, and leisure squares [46-48]. Meanwhile, some researchers took coal-fired power plants and rivers as the study areas [49, 50]. However, the results were rare on risk elements distribution and health risk assessment for children in urban amusement parks. Besides, previous studies neglected the phenomena of risk elements pollution in different urban planning districts due to the influence of various human activities. Therefore, it is indispensable to study topsoil risk elements pollution for amusement parks in Xi'an, and take further measures to prevent risk elements pollution issue.

The purposes of this study were: (1) to measure the concentration of eight risk elements including $\mathrm{Cr}, \mathrm{Ni}, \mathrm{Cu}, \mathrm{Zn}, \mathrm{As}, \mathrm{Pb}, \mathrm{Mn}$, and $\mathrm{Co}$ from four urban amusement parks (the Urban Sports Park (USP), the Xing Qing Park (XQP), the Feng Qing Park (FQP), and the Heritage Park of Tang Dynasty (HPTD)), respectively; (2) to evaluate the pollution level of risk elements through using $\mathrm{I}_{\text {geo }}$ and PLI; (3) to illustrate the

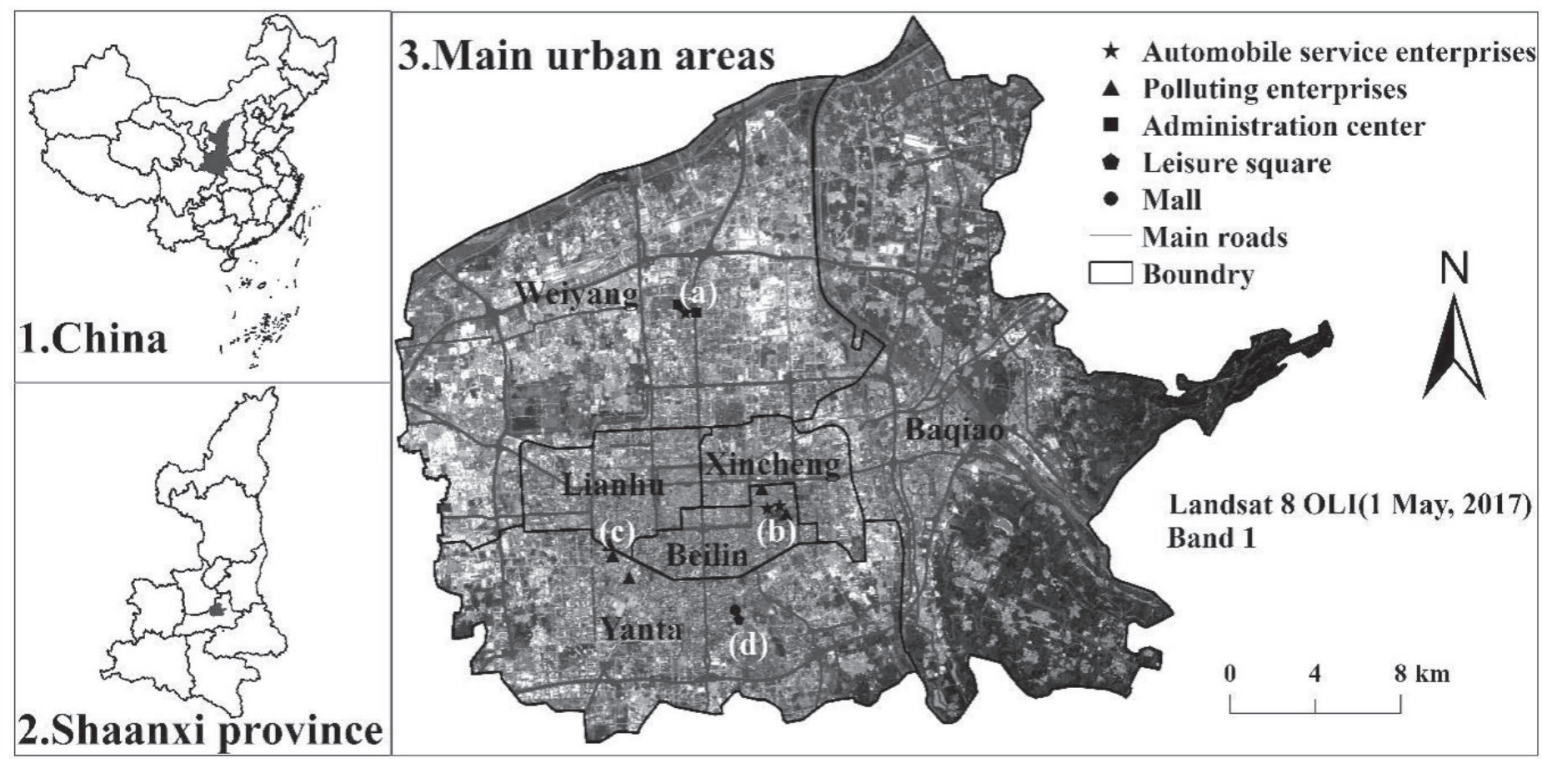

Fig. 1. The map of the study area and the location of soil sampling in Xi'an, China ((a-d) denote the USP, the XQP, the FQP, and the HPTD, respectively). 
spatial distribution of risk elements by a GIS; (4) to evaluate the health risks for children by introducing a health risk model of EPA. This research may provide a scientific suggestion for remediation and pollution treatment for risk elements.

\section{Materials and Methods}

\section{Study Area}

Xi'an is located in the Guan Zhong Basin, northwest China (Fig. 1). The overall terrain is elevated in the north and south and low in the center. It has a warm, temperate, semi-humid, continental monsoon climate with four distinct seasons. The annual average temperature is $15.6^{\circ} \mathrm{C}$, the average annual precipitation is $649.0 \mathrm{~mm}$, and the main soil type is cinnamon soil. Xi'an is a National Central City and an important tourist destination [51-54]. In 2017, it received 18,093,140 visitors from home and abroad, and the GDP was 932.119 billion Yuan ( $1 \$=7.13$ yuan) in 2019. The city has a total area of $10096.81 \mathrm{~km}^{2}$, a built-up area of $832.16 \mathrm{~km}^{2}$, and a population of 4.66 million in the main region, accounting for $47.90 \%$ of the city's total population. In recent years, the speed of expansion was very rapid in Xi'an city. In order to build an international metropolis, the large number of cultivated lands had been transformed into construction lands. At the same time, massive human activities have caused the accumulation of soil risk elements in Xi'an. Furthermore, the economic development and people's living standard have been influenced due to environmental issues. So the Xi'an city has been chosen as the study area in the current study. Meanwhile, we have chosen four parks situated in different urban planning districts as sampling areas to indicate various human activities may generate varying influences on risk elements pollution. According to the urban planning of Xi'an, the north, the south, the west, and the east of Xi'an are the administrative center, educational center, pharmacy and chemical enterprise areas, and textile industry areas, respectively.

\section{Sampling and Analysis}

A total of 111 samples (36 samples from the USP, 33 samples from the XQP, 20 samples from the FQP, and 22 samples from the HPTD) of topsoil $(0-20 \mathrm{~cm})$ [55] were collected on April 1, 2019 (HJ/T166-2004) (Fig. 1). Furthermore, five sub-samples around each sampling site were taken and mixed thoroughly to determine a representative in-situ sample. A portable Global Positioning System (GPS) was used to record the WGS-84 coordinate of each sample site. Besides, polyethylene bags were utilized to store each sample. Soil samples were taken back to the laboratory and airdried. Then, samples were crushed with wood sticks and removed impurities, gravel, and other foreign matters.
Moreover, a GGG-9053AD electric thermostatic airdrying oven was used to dry samples until constant weight [56]. Next, samples were ground and sieved through a $0.7 \mathrm{~mm}$ nylon aperture sieve and were put into clean polyethylene bags for analyzing. Then weighing $4 \mathrm{~g}$ of the soil sample into the $32 \mathrm{~mm}$ mold to squeeze a tablet with boric acid edge under 30 ton pressure for SPECTRO XSORT (A XRF device from Germany). The average value of each sample was taken after three measurements to reduce error. Finally, Sample Result Manager (a specific software for SPECTRO xSORT), R and ArcGIS 10.3 were used for analyzing and mapping in this paper.

The quality assurance and quality control (QA/QC) were evaluated. Soil and sediment standards including the GSS-series and GSD-series geochemical reference materials (Institute of Geophysical and Geochemical Prospecting, Langfang, China) were used to calibrate the device. We have remained some soil samples for validation, and we measured the remained soil samples by calibrated XRF instrument and compared the results with the standard values. Besides, some in-situ soil samples of the present study were sent to Xi'an Institute of Geology and Mineral Resources Experimental Testing Center for measuring contents through the inductively coupled plasma (ICP) instrument. Finally, we found that the relative standard deviation ranged from $3 \%$ to $5 \%$. It proves that the precision of XRF instrument is reliable.

\section{Pollution Assessment Methods}

\section{Geo-accumulation Index ( $\left.I_{\text {geo }}\right)$}

The index of geo-accumulation $\left(\mathrm{I}_{\text {geo }}\right)$ for a single metal was introduced by Muller (1969) [57] to assess risk elements accumulation and pollution level of sediment [58]. (Eq. (1))

$$
I_{g e o}=\log _{2}\left\{\frac{C_{n}}{1.5 * B_{n}}\right\}
$$

...where $I_{g e o}$ is the geo-accumulation index, $C_{n}$ is the measured concentration of risk elements $\mathrm{n}$, and $B_{n}$ is the geochemical background value of risk elements $n$ [59]. In this study, we chose the background value of Shaanxi province as $B_{n}$. The constant 1.5 was introduced to analyze natural fluctuations in the concentration of a given substance in the environment [57], and the $I_{\text {geo }}$ for each risk element was evaluated and classified as follows (Table 1).

\section{Pollution Load Index (PLI)}

CF, developed by Hakanson (1980) [60], denotes the degree of each risk element pollution in soil. The PLI, developed by Tomlinson et al. (1980) [61], can be used to evaluate risk elements contamination levels of various sampling sites at different times and was 
Table 1. The classification standards for the $\mathrm{I}_{\text {gee }}$

\begin{tabular}{|c|c|c|}
\hline Classification & $I_{\text {geo }}$ & Pollution levels \\
\hline 0 & $I_{\text {geo }} \leq 0$ & Uncontaminated \\
\hline 1 & $0<I_{\text {geo }} \leq 1$ & $\begin{array}{c}\text { Uncontaminated to moderately } \\
\text { contaminated }\end{array}$ \\
\hline 2 & $1<I_{g e o} \leq 2$ & Moderately contaminated \\
\hline 3 & $2<I_{g e o} \leq 3$ & $\begin{array}{c}\text { Moderately to heavily } \\
\text { contaminated }\end{array}$ \\
\hline 4 & $3<I_{g e o} \leq 4$ & Heavily contaminated \\
\hline 5 & $4<I_{g e o} \leq 5$ & Heavily to extremely contaminated \\
\hline 6 & 5 & Extremely contaminated \\
\hline
\end{tabular}

utilized to determine the overall contamination levels for all risk elements (Eq. (2), Eq. (3),and Eq. (4)) [62].

$$
\begin{gathered}
C F_{i}=C_{i} / C_{o i} \\
\mathrm{PLI}=\sqrt{C F_{1} \times C F_{2} \times \cdots \times C F_{n}} \\
\mathrm{PLI}_{\text {zone }}=\sqrt[m]{C F_{1} \times C F_{2} \times \cdots \times C F_{n}}
\end{gathered}
$$

...where $C_{i}$ is the measured concentration of ith risk elements, $C_{o i}$ is the geochemical background value for each risk element, and we chose the soil background value of Shaanxi province as $C_{o i}$ (the same to $B_{n}$ in Eq.(1)) [59]. $\mathrm{N}$ is the number of risk elements in soils, $\mathrm{m}$ is the number of sampling sites, $C F_{i}$ is the ith risk element contamination factor, PLI is the pollution load index on a site, and PLI ${ }_{\text {zone }}$ is the pollution load index (Table 2).

\section{Spatial Distribution of Risk Elements}

The Inverse Distance Weight Interpolation (IDW) is a weighted average interpolation method [63]. In this study, the IDW was used to determine the spatial distribution of soil risk elements (Eq. (5) and (6)).

$$
\begin{gathered}
Z(x)=\sum_{i=1}^{n} w_{i} z_{i} \\
w_{i}=d_{i}^{-u}
\end{gathered}
$$

...where $Z(x)$ is the predicted value at an interpolated point, $z_{i}$ denote the value at a known point, $\mathrm{n}$ is the total

Table 2. The classification standards for the PLI.

\begin{tabular}{|c|c|c|}
\hline Classification & PLI & Pollution levels \\
\hline 0 & $\mathrm{PLI}<1$ & Uncontaminated \\
\hline 1 & $1 \leq \mathrm{PLI}<2$ & Moderately contaminated \\
\hline 2 & $2 \leq \mathrm{PLI}<3$ & Heavily contaminated \\
\hline 3 & $\mathrm{PLI} \geq 3$ & Extremely contaminated \\
\hline
\end{tabular}

number of known points used in interpolation, $d_{i}$ is the distance between point $\mathrm{i}$ and the prediction point, $w_{i}$ is the weight assigned to point $\mathrm{i}$, and $\mathrm{u}$ is the weighting power that decides how the weight decreases as the distance increases.

\section{Health Risk Assessment for Risk Elements}

Risk elements enter the human body via three main approaches including direct ingestion, inhalation through nose and mouth, and dermal absorption through exposures $[64,65]$. In this study, health risk models were introduced to evaluate the exposure risk of risk elements for children [66]. $\mathrm{Cr}, \mathrm{Ni}, \mathrm{Cu}, \mathrm{Zn}, \mathrm{As}$, $\mathrm{Pb}, \mathrm{Mn}$, and Co have chronic NCR, and $\mathrm{Cr}, \mathrm{Ni}, \mathrm{As}$ and Co have both CR and NCR. The average daily exposure dose (ADD, mg $\left.\mathrm{kg}^{-1} \cdot \mathrm{d}^{-1}\right)$ of risk elements was calculated as follows (Eq. (7), Eq. (8), and Eq. (9)).

$$
\begin{aligned}
& \text { Oral Intake: } A D D_{\text {ing }}=\frac{C S \times I n g R \times E F \times E D}{B W \times A T} \times 10^{-6} \\
& \text { Inhalation: } A D D_{\text {inh }}=\frac{C S \times \operatorname{Inh} R \times E F \times E D}{P E F \times B W \times A T}
\end{aligned}
$$

Dermal Contact:

$$
A D D_{\text {derm }}=\frac{C S \times S A \times S L \times A B S \times E F \times E D}{B W \times A T} \times 10^{-6}
$$

...where $C S$ is the concentration of risk elements in soil, $(\mathrm{mg} / \mathrm{kg}) ; \operatorname{Ing} R$ and $\operatorname{Inh} R$ are the amount of ingestion and inhalation of risk elements in soil, respectively, $(\mathrm{mg} / \mathrm{d}) ; E F$ is the exposure frequency, (d/a); $E D$ is the exposure duration, (a); $B W$ is the average body weight, (kg); $A T$ is the average exposure time period, (a); $P E F$ is the particle emission factor, $\left(\mathrm{m}^{3} / \mathrm{kg}\right) ; S A$ is the skin exposed area, $\left(\mathrm{cm}^{3}\right)$ [67]; $S L$ is the skin adherence factor, $\left(\mathrm{mg} \cdot\left(\mathrm{cm}^{2} \cdot \mathrm{d}\right)^{-1}\right)$; and $A B S$ is the dermal absorption factor [68]. The daily average exposure of children with carcinogenic risk elements in different exposure routes $\left(L A D D_{i}\right)$ were also calculated by Eq. (7), Eq. (8) and Eq. (9), but the values of AT are different (Table 3).

HQ was chosen to determine the potential NCR of all risk elements through the three pathways (ingestion, inhalation, dermal) (Eq. (10)). There would be a concern for NCR if the HQ>1. The hazard index (HI) was introduced to determine the total potential NCR (Eq. (11)) [19].

$$
\begin{aligned}
& H Q_{i}=\frac{A D D_{i}}{R f D_{i}} \\
& \mathrm{HI}=\sum H Q_{i}
\end{aligned}
$$

...where $A D D_{i}$ denotes average daily exposure dose by ingestion $\left(A D D_{i n g}\right)$, average daily exposure dose by inhalation $\left(A D D_{i n h}\right)$, and average daily exposure dose by dermal absorption $\left(A D D_{\text {drem }}\right)$, respectively $\left(\mathrm{mg} \cdot \mathrm{kg}^{-1} \cdot \mathrm{d}^{-1}\right)$; where $R f D_{i}$ is the homologous reference dose and originates from Table 4 [67] (Table 4). 
Table 3. The parameters of health risk assessment for risk element

\begin{tabular}{|c|c|c|c|c|}
\hline Parameters & Meaning & Units & Value & Data sources \\
\hline $\mathrm{CS}$ & Soil heavy metal content & $\mathrm{mg} \cdot \mathrm{kg}^{-1}$ & $95 \% \mathrm{UCL}$ & Measured by authors \\
\hline IngR & Ingestion rate & $\mathrm{mg} \cdot \mathrm{d}^{-1}$ & 100 & US EPA \\
\hline $\operatorname{InhR}$ & Inhalation rate & $\mathrm{m}^{3} \cdot \mathrm{d}^{-1}$ & 7.6 & US EPA \\
\hline $\mathrm{EF}$ & Exposure frequency & $d \cdot a^{-1}$ & 180 & US EPA \\
\hline ED & Exposure duration & $\mathrm{a}$ & 6 & US EPA \\
\hline BW & Average body weight & $\mathrm{kg}$ & 15 & US EPA \\
\hline \multirow{2}{*}{$\mathrm{AT}$} & \multirow{2}{*}{ Average exposure time } & \multirow{2}{*}{$\mathrm{a}$} & 2190 (NCR) & \multirow{2}{*}{ US EPA } \\
\hline & & & $25550(\mathrm{CR})$ & \\
\hline SA & Skin exposed area & $\mathrm{cm}^{3}$ & 1150 & {$[67]$} \\
\hline SL & Skin adherence factor & $\mathrm{mg} \cdot\left(\mathrm{cm}^{2} \cdot \mathrm{d}\right)^{-1}$ & 0.2 & US EPA \\
\hline PEF & Particle emission factor & $\mathrm{m}^{3} \cdot \mathrm{kg}^{-1}$ & $1.36 \times 10^{9}$ & US EPA \\
\hline ABS & Dermal absorption Factor & - & 0.001 (As is 0.03 ) & {$[68]$} \\
\hline
\end{tabular}

Eq. (12) and Eq. (13) were used to determine the carcinogenic risk $\left(C R_{i}\right)$.

$$
\begin{gathered}
C R_{i}=A D D_{i} \times S F_{i} \\
\mathrm{TCR}=\sum C R_{i}
\end{gathered}
$$

...where $A D D_{i}$ is the same to Eq. (10); $S F_{i}$ is the homologous slope factor of carcinogenic risk elements, $\left((\mathrm{kg} \cdot \mathrm{d}) \cdot \mathrm{mg}^{-1}\right) ; C R_{i}$ is the carcinogenic risk index of each exposure pathway; TCR is the sum of the CR from each exposure pathway. $\mathrm{CR}>10^{-4}$ or $\mathrm{TCR}>10^{-4}$ indicated that there was carcinogenic risk; while $\mathrm{CR}<10^{-6}$, TCR $<10^{-6}$ or $10^{-6}<\mathrm{TCR}<10^{-4}$ indicated that carcinogenic risk could be neglected.

\section{Results and Discussion}

\section{Soil Risk Elements Concentration Statistics}

$\mathrm{Cr}$ was not detected in the USP because the concentration of $\mathrm{Cr}$ was lower than the detection limits of the device. The orders of the average content of risk elements in the USP, XQP, FQP and HPTD were $\mathrm{Mn}>\mathrm{Co}>\mathrm{Zn}>\mathrm{Cu}>\mathrm{Ni}>\mathrm{Pb}>\mathrm{As}, \quad \mathrm{Mn}>\mathrm{Co}>\mathrm{Zn}>\mathrm{Cu}>\mathrm{Cr}>\mathrm{Pb}>$ $\mathrm{Ni}>\mathrm{As}, \quad \mathrm{Mn}>\mathrm{Co}>\mathrm{Zn}>\mathrm{Cu}>\mathrm{Cr}>\mathrm{Pb}>\mathrm{Ni}>\mathrm{As}, \quad \mathrm{Mn}>\mathrm{Co}>\mathrm{Zn}$ $>\mathrm{Cu}>\mathrm{Cr}>\mathrm{Ni}>\mathrm{Pb}>\mathrm{As}$, respectively. Clearly, the content of Mn was the highest. On the contrary, the concentration of As was the lowest in each park (Table 5). In the USP, the coefficient variation (CV) of As was 0.84 and was larger than 0.35 which showed a strong variation $(\mathrm{CV}>0.35)$, the $\mathrm{CV}$ of $\mathrm{Ni}, \mathrm{Zn}, \mathrm{Co}, \mathrm{Pb}$, and $\mathrm{Mn}$ were $0.19,0.15,0.15,0.27,0.21$ and 0.18 respectively, and belonged to medium variation $(0.15<\mathrm{CV}<0.35)$. In the XQP, As with a $\mathrm{CV}$ value of 0.66 belonged to the strong variation, $\mathrm{Cr}$ with a $\mathrm{CV}$ value of 0.35 and close to the strong variation, $\mathrm{CV}$ value of $\mathrm{Ni}, \mathrm{Pb}, \mathrm{Mn}$, and $\mathrm{Co}$ belonged to the medium variation. In the FQP, the $\mathrm{CV}$ value of $\mathrm{As}(0.54)$ and $\mathrm{Zn}(0.37)$ belonged to the strong variation. $\mathrm{CV}$ value of $\mathrm{Cr}(0.24)$ and $\mathrm{Pb}(0.28)$ belonged to the medium variation. In the HPTD, $\mathrm{CV}$ value of $\mathrm{Ni}$ (0.18), As (0.30) and $\mathrm{Pb}(0.16)$ belonged to the medium variation, and $\mathrm{Cr}(0.15)$ and $\mathrm{Co}(0.15)$ were close to medium variation. Besides, the average concentration of risk elements except As have exceeded Shaanxi soil background value [59], and parts of risk elements not only exceeded Shaanxi and China soil background

Table 4. The reference dose and slope factors for different exposure pathways.

\begin{tabular}{|c|c|c|c|c|c|c|c|c|}
\hline Parameters & $\mathrm{Cr}$ & $\mathrm{Ni}$ & $\mathrm{Cu}$ & $\mathrm{Zn}$ & $\mathrm{As}$ & $\mathrm{Pb}$ & $\mathrm{Mn}$ & $\mathrm{Co}$ \\
\hline$R f D_{\text {ing }}$ & $3 \times 10^{-3}$ & $2 \times 10^{-2}$ & $4 \times 10^{-2}$ & $3 \times 10^{-1}$ & $3 \times 10^{-4}$ & $3.5 \times 10^{-3}$ & $4.6 \times 10^{-2}$ & $2 \times 10^{-2}$ \\
\hline$R f D_{\text {inh }}$ & $2.86 \times 10^{-5}$ & $2.06 \times 10^{-2}$ & $4 \times 10^{-2}$ & $3 \times 10^{-1}$ & $3 \times 10^{-4}$ & $3.52 \times 10^{-3}$ & $1.4 \times 10^{-5}$ & $5.71 \times 10^{-6}$ \\
\hline$R f D_{\text {derm }}$ & $6 \times 10^{-5}$ & $5.4 \times 10^{-3}$ & $1.2 \times 10^{-2}$ & $6 \times 10^{-2}$ & $1.23 \times 10^{-4}$ & $5.25 \times 10^{-4}$ & $2.39 \times 10^{-3}$ & $1.6 \times 10^{-2}$ \\
\hline$S F_{\text {ing }}$ & 0.5 & 1.7 & & & 1.5 & & & \\
\hline$S F_{\text {inh }}$ & 42 & 0.84 & & & $4.3 \times 10^{-3}$ & & & 9.8 \\
\hline$S F_{\text {derm }}$ & 2 & 42.5 & & & 1.5 & & & \\
\hline
\end{tabular}


Table 5. The statistics on risk elements contents ( $\mathrm{mg} / \mathrm{kg}$ ).

\begin{tabular}{|c|c|c|c|c|c|c|c|c|c|}
\hline Locations & & $\mathrm{Cr}$ & $\mathrm{Ni}$ & $\mathrm{Cu}$ & $\mathrm{Zn}$ & As & $\mathrm{Pb}$ & $\mathrm{Mn}$ & Co \\
\hline \multirow{3}{*}{$\operatorname{USP}(n=36)$} & Mean & & 38.89 & 79.86 & 159.44 & 5.43 & 38.75 & 844.03 & 248.89 \\
\hline & SD & & 7.47 & 7.22 & 23.84 & 4.55 & 7.96 & 149.65 & 36.26 \\
\hline & $\mathrm{CV}$ & & 0.19 & 0.09 & 0.15 & 0.84 & 0.21 & 0.18 & 0.15 \\
\hline \multirow{3}{*}{$\mathrm{XQP}(\mathrm{n}=33)$} & Mean & 72.27 & 43.79 & 91.36 & 167.42 & 5.76 & 56.97 & 574.39 & 266.82 \\
\hline & SD & 25.41 & 6.96 & 10.02 & 20.92 & 3.81 & 11.45 & 99.55 & 49.73 \\
\hline & $\mathrm{CV}$ & 0.35 & 0.16 & 0.11 & 0.12 & 0.66 & 0.20 & 0.17 & 0.19 \\
\hline \multirow{3}{*}{$\mathrm{FQP}(\mathrm{n}=20)$} & Mean & 81.25 & 36.00 & 101.50 & 196.75 & 7.48 & 63.75 & 579.25 & 240.25 \\
\hline & SD & 19.53 & 3.84 & 13.09 & 72.13 & 4.01 & 17.91 & 75.89 & 30.93 \\
\hline & $\mathrm{CV}$ & 0.24 & 0.11 & 0.13 & 0.37 & 0.54 & 0.28 & 0.13 & 0.13 \\
\hline \multirow{3}{*}{$\operatorname{HPTD}(\mathrm{n}=22)$} & Mean & 66.59 & 36.59 & 74.09 & 135.45 & 9.45 & 32.05 & 570.45 & 256.36 \\
\hline & SD & 10.05 & 6.62 & 8.11 & 13.71 & 2.75 & 5.27 & 22.09 & 38.80 \\
\hline & $\mathrm{CV}$ & 0.15 & 0.18 & 0.11 & 0.10 & 0.30 & 0.16 & 0.04 & 0.15 \\
\hline Shaanxi soil background value & & 62.50 & 28.80 & 21.40 & 69.40 & 11.10 & 21.40 & 557.00 & 10.60 \\
\hline Chinese soil background value & & 61.00 & 26.90 & 22.60 & 72.40 & 11.20 & 26.00 & 583.00 & 12.70 \\
\hline Pan [69] & Mean & 145.0 & 30.8 & 54.7 & 268.6 & & 124.5 & 510.5 & 30.9 \\
\hline Zhang [70] & Mean & 69.8 & 30.7 & 32.4 & 101.3 & 12.2 & 36.9 & 663.3 & 25.0 \\
\hline
\end{tabular}

value but also surpassed the results of previous studies [69, 70]. Furthermore, all elements except As have different degrees of accumulation (Table 5).

\section{Soil Risk Elements Pollution Assessment}

The $I_{\text {geo }}$ was used to evaluate the contamination level for a single risk element (Fig. 2) (Table 6). In the USP, according to the classification of $I_{\text {geo }}$ (Table 1), Ni (-0.16), and As (-1.62) were determined on an uncontaminated level, $\mathrm{Zn}(0.62), \mathrm{Pb}(0.27)$, and

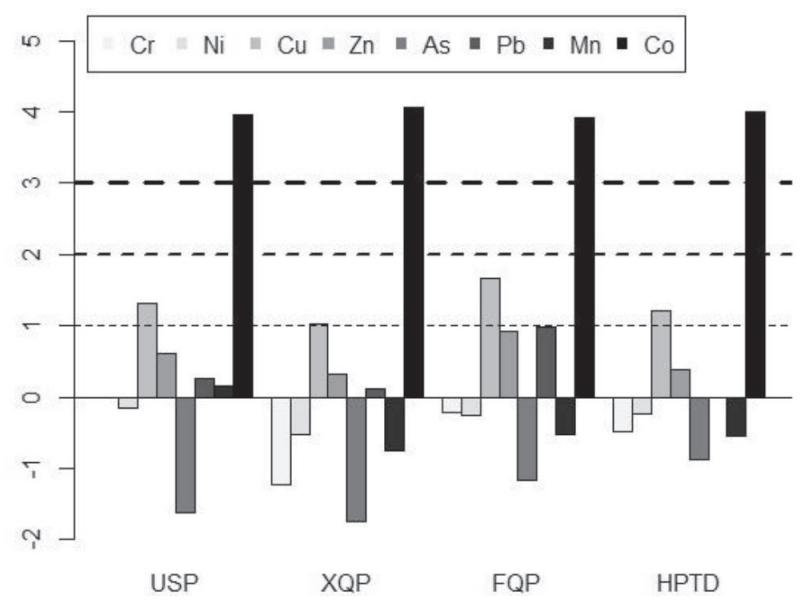

Fig. 2. The $I_{\text {geo }}$ for each metal in four parks (the darkest, the moderate, and the light-colored dashed line denote the thresholds of the heavily contaminated, moderately contaminated, and uncontaminated level, respectively).
Mn (0.15) were determined on an uncontaminated to moderately contaminated level, $\mathrm{Cu}$ (1.31) was determined on a moderately contaminated level, Co (3.97) was determined on a heavily contaminated level. In the XQP, the $I_{\text {geo }}$ values of $\mathrm{Cr}(-1.23)$, Ni (-0.53), As $(-1.74)$, and $\mathrm{Mn}(-0.76)$ were on an uncontaminated level, $\mathrm{Zn}(0.32)$ and $\mathrm{Pb}(0.12)$ belonged to an uncontaminated to moderately contaminated level, $\mathrm{Cu}(1.02)$ was on a moderately contaminated level, Co (4.07) was on a heavily to extremely contaminated level. In the FQP, the pollution levels of risk elements except for Co (3.92) were the same as the XQP. In the HPTD, the $I_{\text {geo }}$ values of $\mathrm{Cr}(-0.49)$, Ni (-0.24), As (-0.88), $\mathrm{Pb}(-0.002)$ and $\mathrm{Mn}(-0.55)$ were on an uncontaminated level, $\mathrm{Zn}(0.38)$ were on an uncontaminated to moderately contaminated level, $\mathrm{Cu}(1.21)$ was on a moderately contaminated level, Co (4.01) was on a heavily to extremely contaminated level. Overall, the contamination level of Co was the highest in each park.

According to the classification of PLI (Table 2), the value of PLI in each park was on a heavily contaminated level (Fig. 3). Clearly, the proportion of contaminated samples was higher than the uncontaminated samples in each park. In the USP, 36 samples were on a heavily contaminated level, and the pollution level of the $21^{\text {st }}$ site with a value of 2.94 was the highest and close to extremely contaminated level. In the XQP, 32 samples were identified as heavily contaminated and 1 site belonged to moderately contaminated level, and the pollution level of the $1^{\text {st }}$ site with a value of 2.84 was the highest. In the FQP, all samples were on a heavily contaminated level, and the contamination level of the 
Table 6. The Igeo for each risk element in four parks.

\begin{tabular}{|c|c|c|c|c|c|c|c|c|}
\hline Locations & $\mathrm{Cr}$ & $\mathrm{Ni}$ & $\mathrm{Cu}$ & $\mathrm{Zn}$ & $\mathrm{As}$ & $\mathrm{Pb}$ & $\mathrm{Mn}$ & $\mathrm{Co}$ \\
\hline USP & & -0.16 & 1.31 & 0.62 & -1.62 & 0.27 & 0.15 & 3.97 \\
\hline XQP & -1.23 & -0.53 & 1.02 & 0.32 & -1.74 & 0.12 & -0.76 & 4.07 \\
\hline FQP & -0.21 & -0.26 & 1.66 & 0.92 & -1.16 & 0.99 & -0.53 & 3.92 \\
\hline HPTD & -0.49 & -0.24 & 1.21 & 0.38 & -0.88 & -0.002 & -0.55 & 4.01 \\
\hline
\end{tabular}

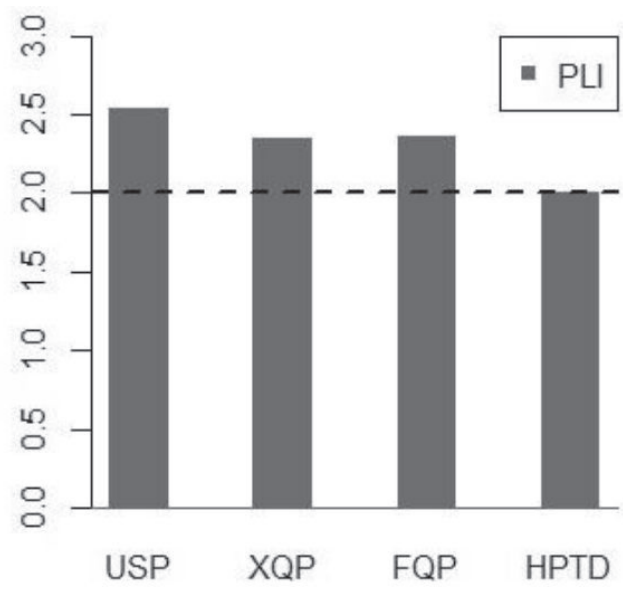

Fig. 3. The PLI for each park (the dashed line denotes the threshold of the heavily contaminated level). $13^{\text {th }}$ site with a value of 2.90 was the highest. In the HPTD, 12 samples were on a heavily contaminated level and 10 samples were identified as moderately contaminated, and the contamination level of the $22^{\text {nd }}$ site with a value of 2.18 was the highest. Obviously, the pollution level of the FQP was determined as the highest and all sites showed heavily contaminated characteristics (Fig. 4).

The $I_{g e o}$ of Co (4.07) in the XQP was the highest due to the park was close to roads and there were a lot of automobile service enterprises around the park (Fig. 1). The PLI of the USP was the largest (2.54) because the park was near to the administration center which was built since 2010s and many building materials were consumed. The XQP with severer risk elements pollution level (2.35) for the park was one of the earliest parks with old entertainment facilities
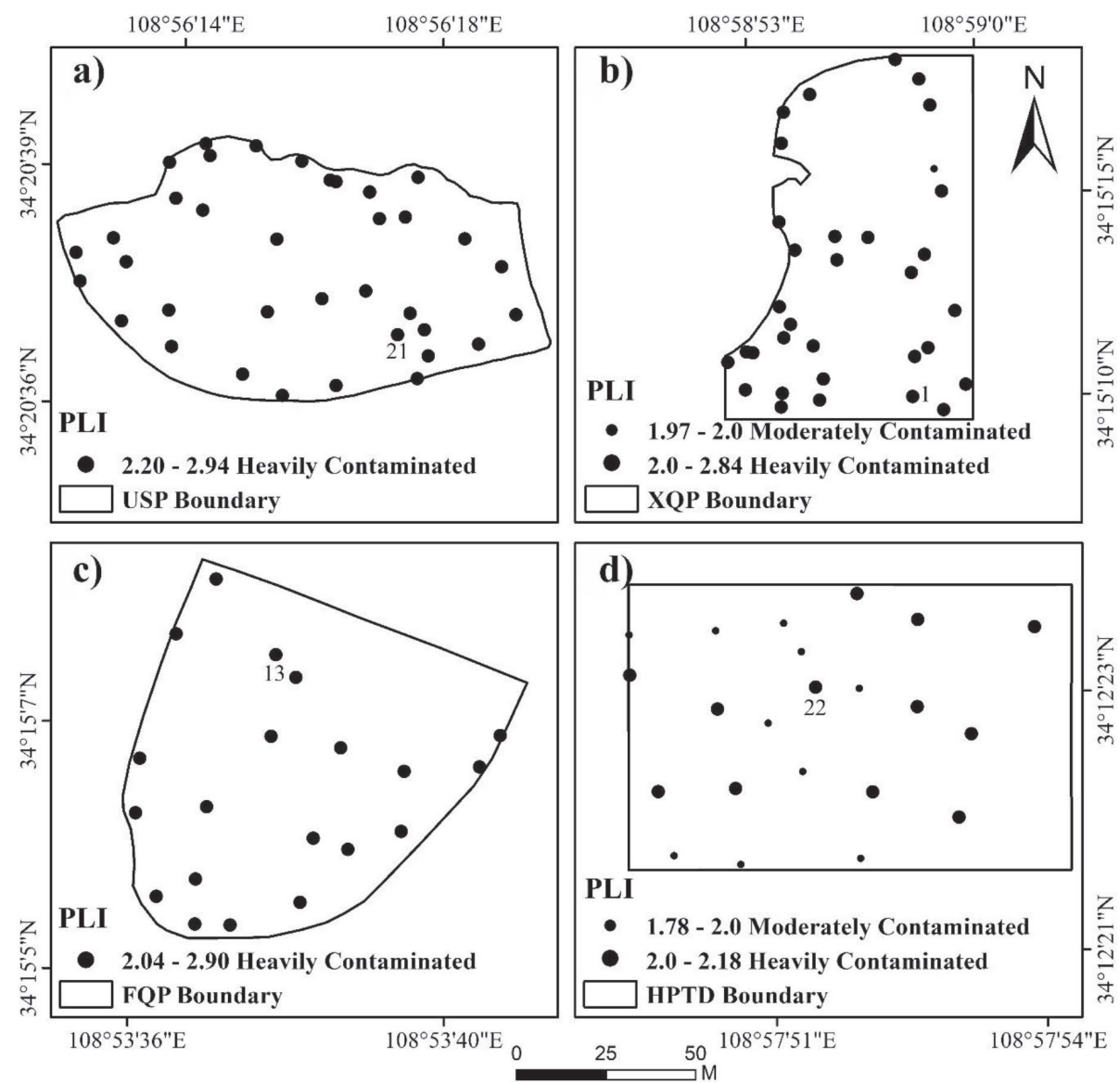

Fig. 4. The maps of PLI for each sample in four parks. 
in Xi'an and the density of roads around the park was high. The FQP located in the western suburbs was a dense area of power and chemical enterprises in Xi'an, which was prone to risk elements accumulation
(Fig. 1).The HPTD was situated in the south suburb of Xi'an with a superb environment condition and without any industrial distribution, so the risk elements pollution level was low in this area. Obviously, the pollution level
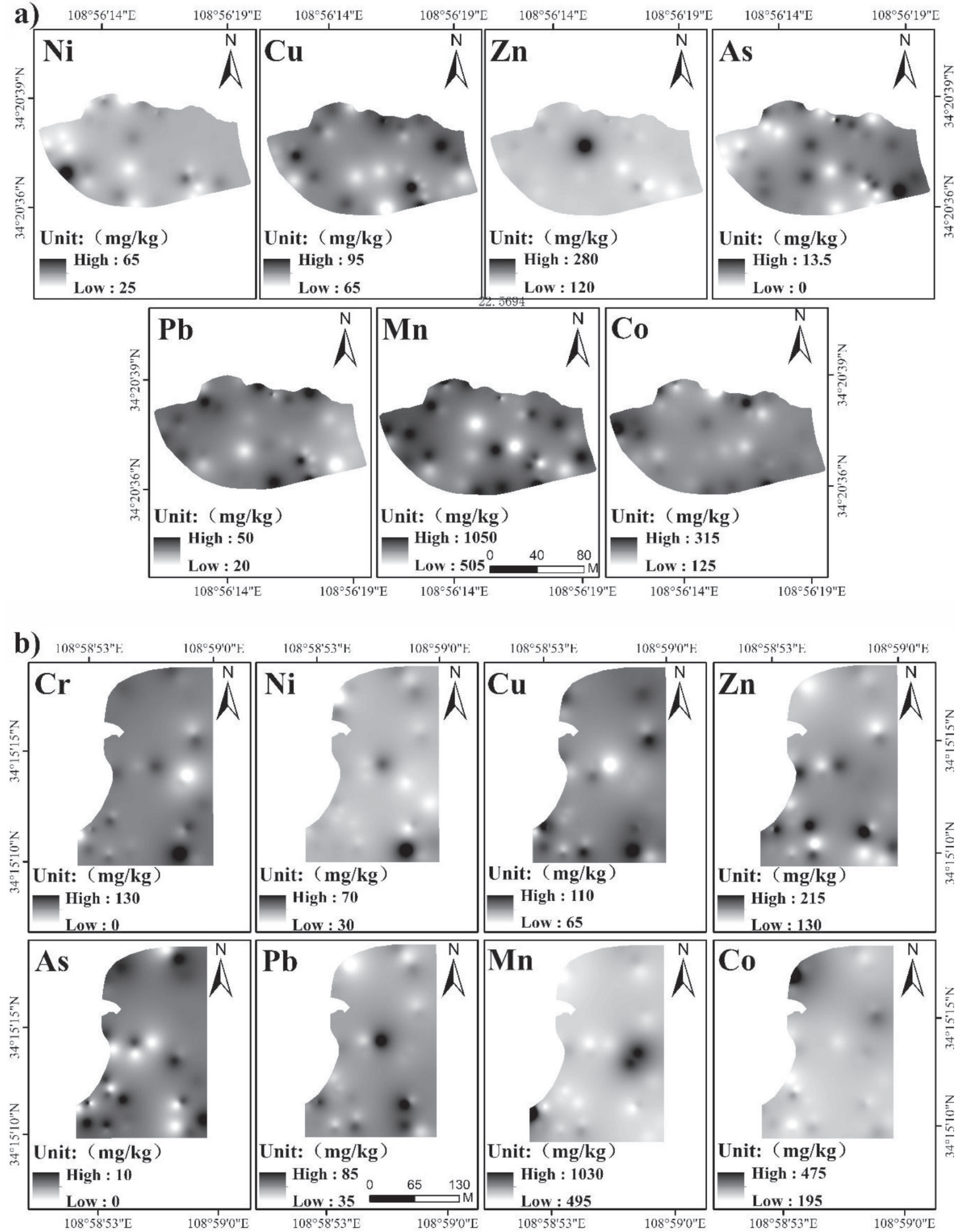

Fig. 5. The spatial distribution maps of metals in four amusement parks in Xi' an ((a-d) denote the USP, the XQP, the FQP, and the HPTD, respectively.) 

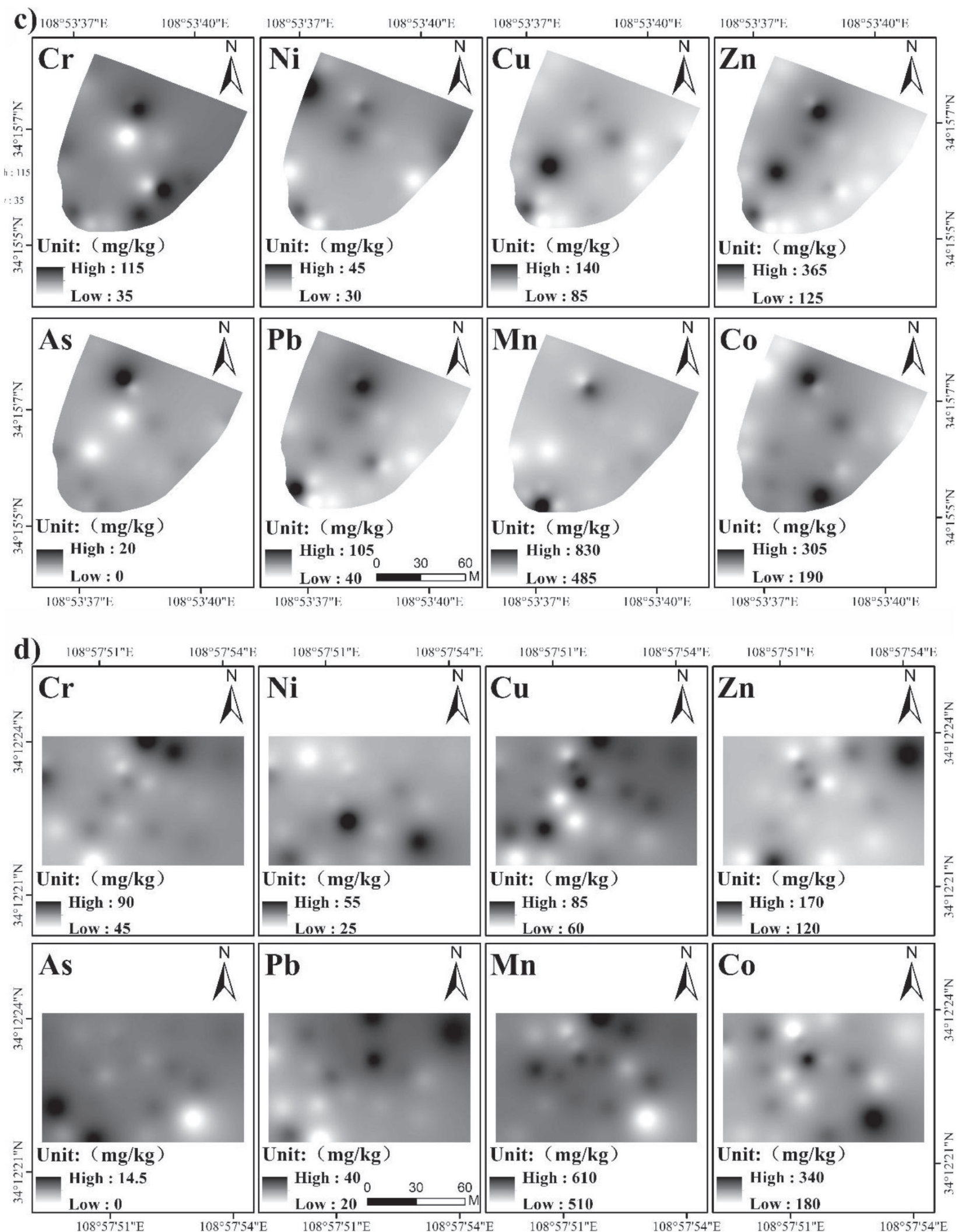

Fig. 5. Continued.

of risk elements showed significant spatial heterogeneity in each park, which implied that the sources of risk elements for four amusement parks were significantly different and mainly caused by human activities.
Spatial Distribution of Risk Elements

Risk elements with similar distribution characteristics may have the same sources. However, 
the distribution characteristics of risk elements in this study were completely different. In the USP, the maps of $\mathrm{Cu}, \mathrm{Pb}, \mathrm{Mn}$, and $\mathrm{Co}$ have the same characteristic and the higher content were around the boundaries because there were four roads around the USP including Wen Jing Road, Feng Cheng Ninth Road, Wei Yang Road and Feng Cheng Eighth Road, the density of roads was high, and a large number of auto repair service enterprises were distributed around the USP (Fig. 1). Besides, the higher content of $\mathrm{Zn}$ mainly distributed in the middle of the park, and the higher content of $\mathrm{Ni}$ located in the southwest of the park. In the XQP, $\mathrm{Cr}, \mathrm{Cu}$, $\mathrm{Co}$, and As mainly distributed around the boundaries and the distribution showed peripheral high and middlelow characteristics (Fig. 5). The higher content of $\mathrm{Zn}$, $\mathrm{Pb}, \mathrm{Mn}$, and Ni mainly distributed in the middle of the park, and there were seven hot spots, four hot spots, two hot spots, and one hot spot with higher content of $\mathrm{Zn}, \mathrm{Pb}, \mathrm{Ni}$, and $\mathrm{Mn}$ inside the park, respectively. The park was adjacent to Xian Ning East Road and Xing Qing Road with large traffic flow in Xi'an. In the FQP, the concentration of $\mathrm{Cr}$ distributed along the road tended to decrease from edge to center because there were three main roads including Tao Yuan Road, Feng Qing Road, and Second Ring Road around the park. The content distribution characteristics of $\mathrm{Ni}$ and As were high in the north and low in the south. The distribution trend of $\mathrm{Cu}, \mathrm{Zn}$, and $\mathrm{Co}$ was increasing from the east and west to the center. $\mathrm{Pb}$ showed a trend of decreasing from northwest to southeast. There was a high concentration of $\mathrm{Mn}$ in partial samples in the south and north. In the HPTD, $\mathrm{Cr}$ and $\mathrm{Pb}$ showed a trend of decreasing from northeast to southwest. Some sites of $\mathrm{Ni}$ element located in the low concentration zone in the northwest of the park, and other samples with higher content located in the south of the park. The higher content of $\mathrm{Zn}$ mainly located in the northeast and southwest of the park. Both As and Mn showed that samples in the southeast were in a low concentration zone and indicated an obvious planar distribution pattern. The distribution of Co was relatively scattered (Fig. 5). In short, the risk elements accumulation

Table 7. The non-carcinogenic and carcinogenic exposure doses for children in different exposure routes.

\begin{tabular}{|c|c|c|c|c|c|c|c|c|c|}
\hline Locations & Parameters & $\mathrm{Cr}$ & $\mathrm{Ni}$ & $\mathrm{Cu}$ & $\mathrm{Zn}$ & As & $\mathrm{Pb}$ & $\mathrm{Mn}$ & Co \\
\hline \multirow{6}{*}{$\begin{array}{c}\text { USP } \\
(\mathrm{n}=36)\end{array}$} & $A D D_{i n g}$ & & $1.28 \times 10^{-4}$ & $2.63 \times 10^{-4}$ & $5.24 \times 10^{-4}$ & $1.79 \times 10^{-5}$ & $1.27 \times 10^{-4}$ & $2.77 \times 10^{-3}$ & $8.18 \times 10^{-4}$ \\
\hline & $A D D_{i n h}$ & & $7.42 \times 10^{-9}$ & $1.52 \times 10^{-8}$ & $3.04 \times 10^{-8}$ & $1.04 \times 10^{-9}$ & $7.39 \times 10^{-9}$ & $1.61 \times 10^{-7}$ & $4.75 \times 10^{-8}$ \\
\hline & $A D D_{\text {derm }}$ & & $2.94 \times 10^{-7}$ & $6.04 \times 10^{-7}$ & $1.21 \times 10^{-6}$ & $1.23 \times 10^{-6}$ & $2.93 \times 10^{-7}$ & $6.38 \times 10^{-6}$ & $1.88 \times 10^{-6}$ \\
\hline & $L A D D_{\text {ing }}$ & & $1.10 \times 10^{-5}$ & & & $1.53 \times 10^{-6}$ & & & $7.01 \times 10^{-5}$ \\
\hline & $L A D D_{i n h}$ & & $6.12 \times 10^{-10}$ & & & $8.55 \times 10^{-11}$ & & & $3.92 \times 10^{-9}$ \\
\hline & $L A D D_{\text {derm }}$ & & $2.52 \times 10^{-8}$ & & & $1.06 \times 10^{-7}$ & & & $1.61 \times 10^{-7}$ \\
\hline \multirow{6}{*}{$\begin{array}{c}\text { XQP } \\
(n=33)\end{array}$} & $A D D_{\text {ing }}$ & $2.38 \times 10^{-4}$ & $1.44 \times 10^{-4}$ & $3.00 \times 10^{-4}$ & $5.50 \times 10^{-4}$ & $1.89 \times 10^{-5}$ & $1.87 \times 10^{-4}$ & $1.89 \times 10^{-3}$ & $8.77 \times 10^{-4}$ \\
\hline & $A D D_{i n h}$ & $1.38 \times 10^{-8}$ & $8.35 \times 10^{-9}$ & $1.74 \times 10^{-8}$ & $3.19 \times 10^{-8}$ & $1.10 \times 10^{-9}$ & $1.09 \times 10^{-8}$ & $1.10 \times 10^{-7}$ & $5.09 \times 10^{-8}$ \\
\hline & $A D D_{\text {derm }}$ & $5.47 \times 10^{-7}$ & $3.31 \times 10^{-7}$ & $6.91 \times 10^{-7}$ & $1.27 \times 10^{-6}$ & $4.35 \times 10^{-8}$ & $4.31 \times 10^{-7}$ & $4.34 \times 10^{-6}$ & $2.02 \times 10^{-6}$ \\
\hline & $L A D D_{\text {ing }}$ & $2.04 \times 10^{-5}$ & $1.23 \times 10^{-5}$ & & & $1.62 \times 10^{-6}$ & & & $7.52 \times 10^{-5}$ \\
\hline & $L A D D_{i n h}$ & $1.14 \times 10^{-9}$ & $6.90 \times 10^{-10}$ & & & $9.07 \times 10^{-11}$ & & & $4.20 \times 10^{-9}$ \\
\hline & $L A D D_{\text {derm }}$ & $4.68 \times 10^{-8}$ & $2.84 \times 10^{-8}$ & & & $3.73 \times 10^{-9}$ & & & $1.73 \times 10^{-7}$ \\
\hline \multirow{6}{*}{$\begin{array}{c}\text { FQP } \\
(n=20)\end{array}$} & $A D D_{\text {ing }}$ & $2.67 \times 10^{-4}$ & $1.18 \times 10^{-4}$ & $3.34 \times 10^{-4}$ & $6.47 \times 10^{-4}$ & $2.46 \times 10^{-5}$ & $2.10 \times 10^{-4}$ & $1.90 \times 10^{-3}$ & $7.90 \times 10^{-4}$ \\
\hline & $A D D_{i n h}$ & $1.55 \times 10^{-8}$ & $6.87 \times 10^{-9}$ & $1.94 \times 10^{-8}$ & $3.75 \times 10^{-8}$ & $1.43 \times 10^{-9}$ & $1.22 \times 10^{-8}$ & $1.11 \times 10^{-7}$ & $4.58 \times 10^{-8}$ \\
\hline & $A D D_{\text {derm }}$ & $6.14 \times 10^{-7}$ & $2.72 \times 10^{-7}$ & $7.68 \times 10^{-7}$ & $1.49 \times 10^{-6}$ & $5.65 \times 10^{-8}$ & $4.82 \times 10^{-7}$ & $4.38 \times 10^{-6}$ & $1.82 \times 10^{-6}$ \\
\hline & $L A D D_{\text {ing }}$ & $2.29 \times 10^{-5}$ & $1.01 \times 10^{-5}$ & & & $2.11 \times 10^{-6}$ & & & $6.77 \times 10^{-5}$ \\
\hline & $L A D D_{i n h}$ & $1.28 \times 10^{-9}$ & $5.67 \times 10^{-10}$ & & & $1.18 \times 10^{-10}$ & & & $3.78 \times 10^{-9}$ \\
\hline & $L A D D_{\text {derm }}$ & $5.27 \times 10^{-8}$ & $2.33 \times 10^{-8}$ & & & $4.84 \times 10^{-9}$ & & & $1.56 \times 10^{-7}$ \\
\hline \multirow{6}{*}{$\begin{array}{l}\text { HPTD } \\
(\mathrm{n}=22)\end{array}$} & $A D D_{\text {ing }}$ & $2.19 \times 10^{-4}$ & $1.20 \times 10^{-4}$ & $2.44 \times 10^{-4}$ & $4.45 \times 10^{-4}$ & $2.97 \times 10^{-5}$ & $1.05 \times 10^{-4}$ & $1.88 \times 10^{-3}$ & $8.43 \times 10^{-4}$ \\
\hline & $A D D_{i n h}$ & $1.27 \times 10^{-8}$ & $6.98 \times 10^{-9}$ & $1.41 \times 10^{-8}$ & $2.58 \times 10^{-8}$ & $1.72 \times 10^{-9}$ & $6.11 \times 10^{-9}$ & $1.09 \times 10^{-7}$ & $4.89 \times 10^{-8}$ \\
\hline & $A D D_{\text {derm }}$ & $5.04 \times 10^{-7}$ & $2.77 \times 10^{-7}$ & $5.60 \times 10^{-7}$ & $1.02 \times 10^{-6}$ & $6.82 \times 10^{-8}$ & $2.42 \times 10^{-7}$ & $4.31 \times 10^{-6}$ & $1.94 \times 10^{-6}$ \\
\hline & $L A D D_{\text {ing }}$ & $1.88 \times 10^{-5}$ & $1.03 \times 10^{-5}$ & & & $2.54 \times 10^{-6}$ & & & $7.22 \times 10^{-5}$ \\
\hline & $L A D D_{i n h}$ & $1.05 \times 10^{-9}$ & $5.76 \times 10^{-10}$ & & & $1.42 \times 10^{-10}$ & & & $4.04 \times 10^{-9}$ \\
\hline & $L A D D_{\text {derm }}$ & $4.32 \times 10^{-8}$ & $2.37 \times 10^{-8}$ & & & $5.85 \times 10^{-9}$ & & & $1.66 \times 10^{-7}$ \\
\hline
\end{tabular}


were affected by many factors, this study showed that human activities play a significant role in risk elements distribution.

\section{Health Risk Assessment of Risk Elements}

The average daily exposure doses orders for NCR risk elements through three pathways in the USP, the $\mathrm{XQP}$ and FQP, and the HPTD were $\mathrm{Mn}>\mathrm{Co}>\mathrm{Zn}>\mathrm{Cu}>$ $\mathrm{Ni}>\mathrm{Pb}>\mathrm{As}, \quad \mathrm{Mn}>\mathrm{Co}>\mathrm{Zn}>\mathrm{Cu}>\mathrm{Cr}>\mathrm{Pb}>\mathrm{Ni}>\mathrm{As}, \quad$ and $\mathrm{Mn}>\mathrm{Co}>\mathrm{Zn}>\mathrm{Cu}>\mathrm{Cr}>\mathrm{Pb}>\mathrm{Ni}>\mathrm{As}$, respectively. And the $\mathrm{CR}$ risk elements through three pathways in the
USP, the XQP and FQP, and the HPTD were $\mathrm{Co}>\mathrm{Ni}>\mathrm{As}$, $\mathrm{Co}>\mathrm{Cr}>\mathrm{Ni}>\mathrm{As}$, and $\mathrm{Co}>\mathrm{Cr}>\mathrm{Ni}>\mathrm{As}$, respectively. The exposure pathways order for $\mathrm{CR}$ and NCR were oral intake $>$ dermal contact $>$ inhalation in each park. Clearly, in each park, the largest average daily exposure doses of NCR were Mn element, the largest average daily exposure doses of $\mathrm{CR}$ were Co element, and the main exposure route was oral intake (Table 7).

The value of HI and HQ were less than one indicated that there was no NCR for all observed risk elements. For CR risk elements, the value of $\mathrm{CR}$ and TCR were less than $10^{-6}$ or in the range of $10^{-6}$ to $10^{-4}$, and

Table 8. The non-carcinogenic and carcinogenic risks of risk elements in different parks in Xi'an.

\begin{tabular}{|c|c|c|c|c|c|c|c|c|c|}
\hline Locations & Parameters & $\mathrm{Cr}$ & $\mathrm{Ni}$ & $\mathrm{Cu}$ & $\mathrm{Zn}$ & As & $\mathrm{Pb}$ & $\mathrm{Mn}$ & Co \\
\hline \multirow{10}{*}{$\begin{array}{c}\text { USP } \\
(\mathrm{n}=36)\end{array}$} & $\mathrm{HQ}_{\text {ing }}$ & & $6.39 \times 10^{-3}$ & $6.56 \times 10^{-3}$ & $1.75 \times 10^{-3}$ & $5.95 \times 10^{-2}$ & $3.64 \times 10^{-2}$ & $6.03 \times 10^{-2}$ & $4.09 \times 10^{-2}$ \\
\hline & $\mathrm{HQ}_{i n h}$ & & $3.60 \times 10^{-7}$ & $3.81 \times 10^{-7}$ & $1.01 \times 10^{-7}$ & $3.45 \times 10^{-6}$ & $2.10 \times 10^{-6}$ & $1.15 \times 10^{-2}$ & $8.32 \times 10^{-3}$ \\
\hline & $\mathrm{HQ}_{\text {derm }}$ & & $5.45 \times 10^{-5}$ & $5.03 \times 10^{-5}$ & $2.01 \times 10^{-5}$ & $1.00 \times 10^{-2}$ & $5.58 \times 10^{-4}$ & $2.67 \times 10^{-3}$ & $1.18 \times 10^{-4}$ \\
\hline & HI & & $6.45 \times 10^{-3}$ & $6.61 \times 10^{-3}$ & $1.77 \times 10^{-3}$ & $6.95 \times 10^{-2}$ & $3.70 \times 10^{-2}$ & $7.45 \times 10^{-2}$ & $4.93 \times 10^{-2}$ \\
\hline & Total HI & \multicolumn{8}{|c|}{0.245} \\
\hline & $C R_{\text {ing }}$ & & $1.86 \times 10^{-5}$ & & & $2.30 \times 10^{-6}$ & & & \\
\hline & $C R_{i n h}$ & & $5.14 \times 10^{-10}$ & & & $3.68 \times 10^{-13}$ & & & $3.84 \times 10^{-8}$ \\
\hline & $\mathrm{CR}_{\text {derm }}$ & & $1.07 \times 10^{-6}$ & & & $1.58 \times 10^{-7}$ & & & \\
\hline & $\mathrm{CR}$ & & $1.97 \times 10^{-5}$ & & & $2.45 \times 10^{-6}$ & & & $3.84 \times 10^{-8}$ \\
\hline & Total CR & \multicolumn{8}{|c|}{$2.22 \times 10^{-5}$} \\
\hline \multirow{10}{*}{$\begin{array}{c}\text { XQP } \\
(n=33)\end{array}$} & $\mathrm{HQ}_{i n g}$ & $7.92 \times 10^{-2}$ & $7.20 \times 10^{-3}$ & $7.51 \times 10^{-3}$ & $1.83 \times 10^{-3}$ & $6.31 \times 10^{-2}$ & $5.35 \times 10^{-2}$ & $4.11 \times 10^{-2}$ & $4.39 \times 10^{-2}$ \\
\hline & $\mathrm{HQ}_{i n h}$ & $4.82 \times 10^{-4}$ & $4.06 \times 10^{-7}$ & $4.36 \times 10^{-7}$ & $1.06 \times 10^{-7}$ & $3.66 \times 10^{-6}$ & $3.09 \times 10^{-6}$ & $7.83 \times 10^{-3}$ & $8.91 \times 10^{-3}$ \\
\hline & $\mathrm{HQ}_{\text {derm }}$ & $9.11 \times 10^{-3}$ & $6.13 \times 10^{-5}$ & $5.76 \times 10^{-5}$ & $2.11 \times 10^{-5}$ & $3.54 \times 10^{-4}$ & $8.21 \times 10^{-4}$ & $1.82 \times 10^{-3}$ & $1.26 \times 10^{-4}$ \\
\hline & $\mathrm{HI}$ & $8.88 \times 10^{-2}$ & $7.26 \times 10^{-3}$ & $7.57 \times 10^{-3}$ & $1.86 \times 10^{-3}$ & $6.35 \times 10^{-2}$ & $5.43 \times 10^{-2}$ & $5.07 \times 10^{-2}$ & $5.29 \times 10^{-2}$ \\
\hline & Total HI & \multicolumn{8}{|c|}{0.327} \\
\hline & $C R_{\text {ing }}$ & $1.02 \times 10^{-5}$ & $2.10 \times 10^{-5}$ & & & $2.43 \times 10^{-6}$ & & & \\
\hline & $C R_{i n h}$ & $4.78 \times 10^{-8}$ & $5.79 \times 10^{-10}$ & & & $3.90 \times 10^{-13}$ & & & $4.12 \times 10^{-8}$ \\
\hline & $\mathrm{CR}_{\text {derm }}$ & $9.37 \times 10^{-8}$ & $1.21 \times 10^{-6}$ & & & $5.60 \times 10^{-9}$ & & & \\
\hline & $\mathrm{CR}$ & $1.03 \times 10^{-5}$ & $2.22 \times 10^{-5}$ & & & $2.44 \times 10^{-6}$ & & & $4.12 \times 10^{-8}$ \\
\hline & Total CR & \multicolumn{8}{|c|}{$3.50 \times 10^{-5}$} \\
\hline \multirow{10}{*}{$\begin{array}{c}\text { FQP } \\
(\mathrm{n}=20)\end{array}$} & $\mathrm{HQ}_{i n g}$ & $8.90 \times 10^{-2}$ & $5.92 \times 10^{-3}$ & $8.34 \times 10^{-3}$ & $2.16 \times 10^{-3}$ & $8.19 \times 10^{-2}$ & $5.99 \times 10^{-2}$ & $4.14 \times 10^{-2}$ & $3.95 \times 10^{-2}$ \\
\hline & $\mathrm{HQ}_{i n h}$ & $5.42 \times 10^{-4}$ & $3.33 \times 10^{-7}$ & $4.84 \times 10^{-7}$ & $1.25 \times 10^{-7}$ & $4.75 \times 10^{-6}$ & $3.46 \times 10^{-6}$ & $7.89 \times 10^{-3}$ & $8.03 \times 10^{-3}$ \\
\hline & $\mathrm{HQ}_{\text {derm }}$ & $1.02 \times 10^{-2}$ & $5.04 \times 10^{-5}$ & $6.40 \times 10^{-5}$ & $2.48 \times 10^{-5}$ & $4.60 \times 10^{-4}$ & $9.18 \times 10^{-4}$ & $1.83 \times 10^{-3}$ & $1.14 \times 10^{-4}$ \\
\hline & $\mathrm{HI}$ & $9.98 \times 10^{-2}$ & $5.97 \times 10^{-3}$ & $8.41 \times 10^{-3}$ & $2.18 \times 10^{-3}$ & $8.24 \times 10^{-2}$ & $6.08 \times 10^{-2}$ & $5.11 \times 10^{-2}$ & $4.76 \times 10^{-2}$ \\
\hline & Total HI & \multicolumn{8}{|c|}{0.358} \\
\hline & $C R_{\text {ing }}$ & $1.14 \times 10^{-5}$ & $1.72 \times 10^{-5}$ & & & $3.16 \times 10^{-6}$ & & & \\
\hline & $C R_{i n h}$ & $5.37 \times 10^{-8}$ & $4.76 \times 10^{-10}$ & & & $5.06 \times 10^{-13}$ & & & $3.71 \times 10^{-8}$ \\
\hline & $\mathrm{CR}_{\text {derm }}$ & $1.05 \times 10^{-7}$ & $9.92 \times 10^{-7}$ & & & $7.27 \times 10^{-9}$ & & & \\
\hline & $\mathrm{CR}$ & $1.16 \times 10^{-5}$ & $1.82 \times 10^{-5}$ & & & $3.17 \times 10^{-6}$ & & & $3.71 \times 10^{-8}$ \\
\hline & Total CR & \multicolumn{8}{|c|}{$3.30 \times 10^{-5}$} \\
\hline
\end{tabular}


Table 8. Continued.

\begin{tabular}{|c|c|c|c|c|c|c|c|c|c|}
\hline \multirow{10}{*}{$\begin{array}{c}\text { HPTD } \\
(\mathrm{n}=22)\end{array}$} & $\mathrm{HQ}_{i n g}$ & $7.30 \times 10^{-2}$ & $6.01 \times 10^{-3}$ & $6.09 \times 10^{-3}$ & $1.48 \times 10^{-3}$ & $9.89 \times 10^{-2}$ & $3.01 \times 10^{-2}$ & $4.08 \times 10^{-2}$ & $4.21 \times 10^{-2}$ \\
\hline & $\mathrm{HQ}_{i n h}$ & $4.44 \times 10^{-4}$ & $3.39 \times 10^{-7}$ & $3.53 \times 10^{-7}$ & $8.61 \times 10^{-8}$ & $5.74 \times 10^{-6}$ & $1.74 \times 10^{-6}$ & $7.77 \times 10^{-3}$ & $8.57 \times 10^{-3}$ \\
\hline & $\mathrm{HQ}_{\text {derm }}$ & $8.39 \times 10^{-3}$ & $5.12 \times 10^{-5}$ & $4.67 \times 10^{-5}$ & $1.71 \times 10^{-5}$ & $5.55 \times 10^{-4}$ & $4.62 \times 10^{-4}$ & $1.80 \times 10^{-3}$ & $1.21 \times 10^{-4}$ \\
\hline & $\mathrm{HI}$ & $8.18 \times 10^{-2}$ & $6.07 \times 10^{-3}$ & $6.14 \times 10^{-3}$ & $1.50 \times 10^{-3}$ & $9.94 \times 10^{-2}$ & $3.06 \times 10^{-2}$ & $5.03 \times 10^{-2}$ & $5.08 \times 10^{-2}$ \\
\hline & Total HI & \multicolumn{8}{|c|}{0.327} \\
\hline & $C R_{\text {ing }}$ & $9.38 \times 10^{-6}$ & $1.75 \times 10^{-5}$ & & & $3.81 \times 10^{-6}$ & & & \\
\hline & $C R_{i n h}$ & $4.40 \times 10^{-8}$ & $4.84 \times 10^{-10}$ & & & $6.11 \times 10^{-13}$ & & & $3.96 \times 10^{-8}$ \\
\hline & $\mathrm{CR}_{\text {derm }}$ & $8.63 \times 10^{-8}$ & $1.01 \times 10^{-6}$ & & & $8.77 \times 10^{-9}$ & & & \\
\hline & $\mathrm{CR}$ & $9.51 \times 10^{-6}$ & $1.85 \times 10^{-5}$ & & & $3.82 \times 10^{-6}$ & & & $3.96 \times 10^{-8}$ \\
\hline & Total CR & \multicolumn{8}{|c|}{$3.19 \times 10^{-5}$} \\
\hline
\end{tabular}

the $\mathrm{CR}$ can be ignored according to the USEPA. Besides, the maximum NCR of risk elements was found in the FQP, and the NCR could be ignored. The rank for NCR was $F Q P>X Q P=H P T D>U S P$. For $C R$, the maximum value appeared in the XQP, and the CR of all metal elements were within the safe range. The rank for CR was $\mathrm{XQP}>\mathrm{FQP}>\mathrm{HPTD}>\mathrm{USP}$ (Table 8).

\section{Analyzing for Risk Elements Concentration}

The Mn concentration was the highest in each park because the natural factors had been identified as the main source in previous studies [71]. Besides, some reports suggested the accumulation of $\mathrm{Mn}$ in the soil might be affected by industrial activities $[72,73]$. The Mn concentration was higher than the background value in the USP, which might have been significantly influenced by anthropocentric activities (Table 5). Meanwhile, As concentration was affected by soilforming factors lower than the background value in each park, and the main sources of As element were coal combustion and steel smelting [74, 75]. What's more, Co concentration was twenty times higher than the background value in each park. The possible sources for Co might be from coal combustion, metallurgical industry, automobile tire corrosion, and automobile exhaust [76]. Besides, many researches had reported that $\mathrm{Cu}$ was mainly used in mechanical parts [77], and the emission of automobile exhaust was the main source of $\mathrm{Pb}$ in urban environment [78-80]. The main source of $\mathrm{Cr}$ was from burning of fossil fuels [81, 82]. The corrosion of zinc-plated automobile parts was the main source of $\mathrm{Zn}$ in urban soil [83]. Besides, the $\mathrm{CV}$ can be used to reflect the degree of influence of humans for risk elements. The higher $\mathrm{CV}$ indicated that risk elements concentration were more likely to be affected by human activities. In this study, the CV for each metal showed completely different and revealed the sources for risk elements were different.
Correlation analysis was applied to identify the sources for risk elements in this study. According to Pearson correlation analysis (Table 9), $\mathrm{Cu}$ and $\mathrm{Zn}$ were significantly correlated to each other $(\mathrm{P}<0.01)$ and revealed a common origin for these two elements, most probably anthropogenic activities, such as industrial activities. $\mathrm{Pb}, \mathrm{Cu}$, and $\mathrm{Zn}$ were strongly correlated with each other $(\mathrm{P}<0.01)$ and indicated they originated from the same emission sources such as automobile exhaust and tire wear. Besides, $\mathrm{Ni}$ and $\mathrm{Cr}(\mathrm{P}<0.01), \mathrm{Co}$ and $\mathrm{As}$ $(\mathrm{P}<0.05), \mathrm{Mn}$ and $\mathrm{Pb}(\mathrm{P}<0.01)$, As and $\mathrm{Zn}(\mathrm{P}<0.05)$, and $\mathrm{Mn}$ and As $(\mathrm{P}<0.05)$ also were correlated with each other. These results were similar to previous studies, such as $\mathrm{Cd}$ and $\mathrm{Cu}$ were good indicators of pollution in soil and markers of traffic emission [84]. As and $\mathrm{Pb}$ were from coal combustion and fossil fuels [74]. Mn and $\mathrm{Ni}$ were correlated with $\mathrm{Hg}$ and As significantly and showed that they were influenced by the coal fired source emissions.

\section{Measures for Reducing Health Risk}

First, the wastes discharged by factories around the parks should be treated with purification and be strictly controlled to meet the emission standards. Second, old vehicles should be limited to use. Besides, the government should encourage people to buy new energy vehicles including electric vehicles and ethanol vehicles and recommend people to use public transportation to reduce the use of private cars. Third, the modified inhibitors (such as lime, phosphate and calcium silicate, etc.) should be applied to the soil to make them interact with risk elements to produce insoluble compounds and reduce the migration capacity of risk elements into the soil and plants. Besides, public awareness of environmental protection should be strengthened, and garbage classification, especially for risk elements enriched garbage (such as batteries, paint, smelting, hardware, machinery, electroplating, cosmetics, etc.) should be advocated for recycling and treatment. Finally, the results showed that oral ingestion was the 
Table 9. The correlation matrix of risk elements contents in four parks.

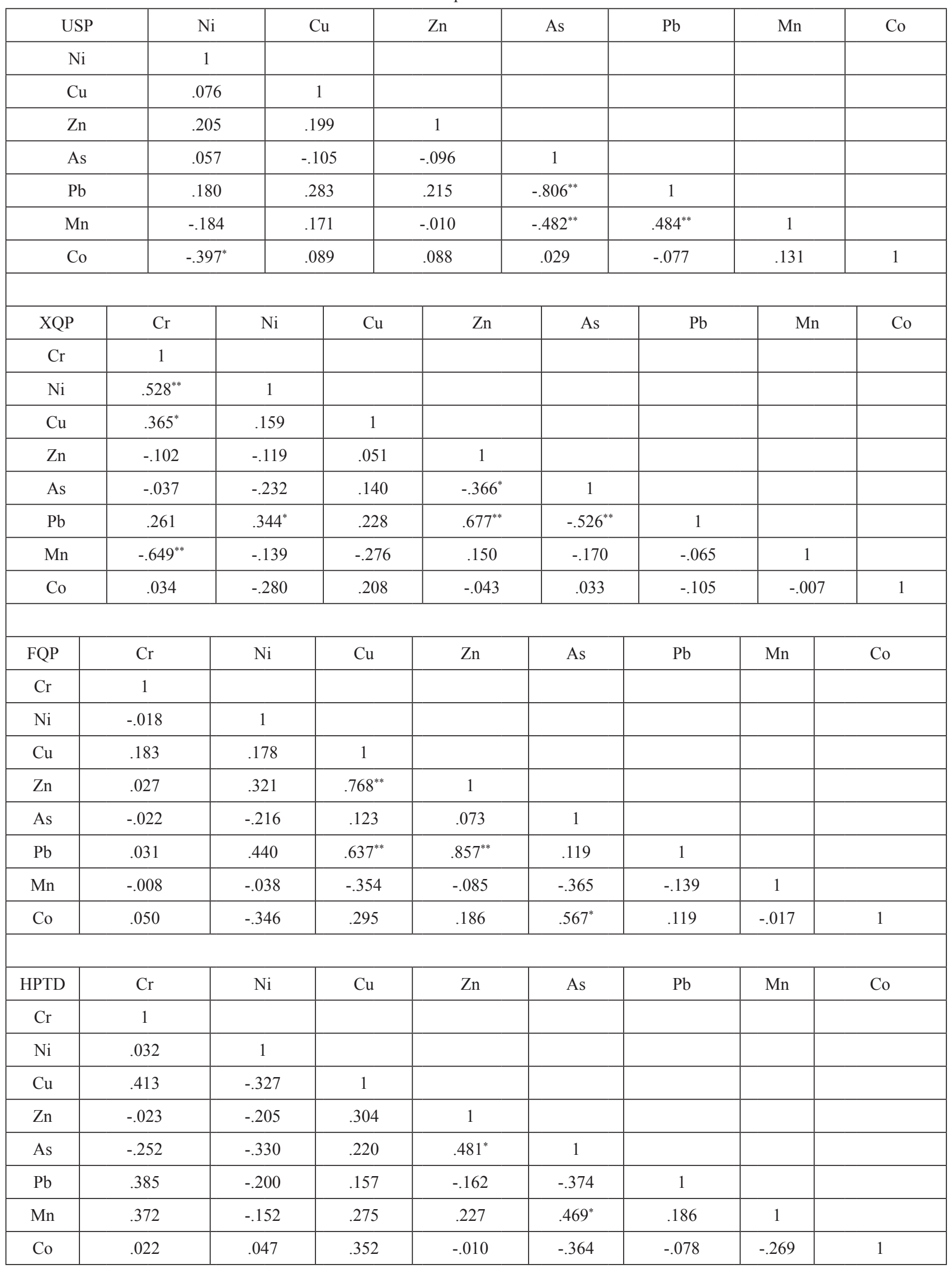

*. Correlation is significant at the 0.05 level (two-tailed).

**. Correlation is significant at the 0.01 level (two-tailed). 
primary exposure route for children. Therefore, we strongly recommend that children's playgrounds should be covered with materials such as plastic, lawn or wood chips to block the access chance of the soil for children in activity areas.

\section{Conclusions}

With the rapid development of urbanization, the topsoil of amusement parks in Xi'an were slightly contaminated by risk elements. This study tried to map the distribution and evaluate the health risk of risk elements by GIS and models. The concentration of certain risk elements $(\mathrm{Ni}, \mathrm{Cu}, \mathrm{Zn}$, $\mathrm{Pb}, \mathrm{Mn}, \mathrm{Cr}$, and $\mathrm{Co}$ ) exceeded the Shaanxi soil background value with following decreasing trend $(\mathrm{Mn}>\mathrm{Co}>\mathrm{Zn}>\mathrm{Cu}>\mathrm{Ni}>\mathrm{Pb}>\mathrm{As})$ in the USP, with following decreasing trend $(\mathrm{Mn}>\mathrm{Co}>\mathrm{Zn}>\mathrm{Cu}>\mathrm{Cr}>\mathrm{Pb}>\mathrm{Ni}>\mathrm{As})$ in the $\mathrm{XQP}$ and $\mathrm{FQP}$, and with following decreasing trend $(\mathrm{Mn}>\mathrm{Co}>\mathrm{Zn}>\mathrm{Cu}>\mathrm{Cr}>\mathrm{Ni}>\mathrm{Pb}>\mathrm{As})$ in the HPTD. The risk elements showed significant variation among the four amusement parks, and different distribution characteristics in the concentration were found. The $I_{\text {geo }}$ of $\mathrm{Co}$ exhibited the highest contamination level in four amusement parks. The PLI exhibited a high contamination level in the USP. The results showed that the sources for risk elements were strongly affected by human activities. Fuel combustion, vehicle exhaust, and polluted enterprises may be the main sources of risk elements in Xi'an. The results of health risk assessments revealed that oral intake posed higher risks than other pathways for children. All of the elements showed there were no NCR and CR risks in the study areas. This study can supply a reference for further researches of risk elements pollution in other cities and provide a scientific basis for risk elements pollution treatment. Furthermore, it can urge the government to pay more attention for risk elements contamination in the northwestern cities of China.

\section{Acknowledgements}

This research was supported by the Fund Project of Shaanxi Key Laboratory of Land Consolidation (grant: 2019-JC11) and Scientific research project of Shaanxi Provincial Department of Education (grant: 16JK1495). Thanks for the syntax checking from Master candidate Yi Bian and Master candidate Yan Wang. We are deeply grateful to Master Yong Zhang and Master Qianjin Cheng for supplying technique supporting in the concerned experiment.

\section{Conflict of Interest}

The authors declare no conflict of interest.

\section{Reference}

1. HOU D.Y., O'CONNOR D., NATHANAIL P., TIAN L., MA Y. Integrated GIS and multivariate statistical analysis for regional scale assessment of risk elements soil contamination: A critical review. Environ Pollut, 231, 1188, 2017.

2. LI P.Y., WU J.H., QIAN H., LYU X.S., LIU H.W. Origin and assessment of groundwater pollution and associated health risk: A case study in an industrial park, northwest China. Environmental Geochemistry \& Health, 36 (4), 693, 2014.

3. SOLGI E., ESMAILI-SARI A., RIYAHI-BAKHTIARI A., HADIPOUR M. Soil Contamination of Metals in the Three Industrial Estates, Arak, Iran. B Environ Contam Tox, 88 (4), 634, 2012.

4. YANG Q.Q., LI Z.Y., LU X.N., DUAN Q.N., HUANG L., BI J. A review of soil risk elements pollution from industrial and agricultural regions in China: Pollution and risk assessment. Sci Total Environ, 642, 690, 2018.

5. RODRÍGUEZ-EUGENIO N., MCLAUGHLIN M., PENNOCK D. Soil pollution: a hidden reality, FAO: pp. 142, 2018.

6. ALSHAHRI F., EL-TAHER A. Assessment of Heavy and Trace Metals in Surface Soil Nearby an Oil Refinery, Saudi Arabia, Using Geoaccumulation and Pollution Indices. Archives of Environmental Contamination \& Toxicology, 75 (3), 390, 2018

7. LIU K., WANG F., LI J.W., TIWARI S., CHEN B. Assessment of trends and emission sources of risk elements from the soil sediments near the Bohai Bay. Environ Sci Pollut R, 26 (28), 29095, 2019.

8. CHENG X.F., DANEK T., DROZDOVA J., HUANG Q.R., QI W.F., ZOU L.L., YANG S.R., ZHAO X.L., XIANG Y.G. Soil risk elements pollution and risk assessment associated with the $\mathrm{Zn}-\mathrm{Pb}$ mining region in Yunnan, Southwest China. Environ Monit Assess, 190 (4), 194, 2018.

9. GATTA G., GAGLIARDI A., DISCIGLIO G., LONIGRO A., FRANCAVILLA M., TARANTINO E., GIULIANI M.M. Irrigation with treated municipal wastewater on artichoke crop: assessment of soil and yield risk elements content and human risk. Water-Sui, 10 (3), 255, 2018.

10. GUAN Q.Y., ZHAO R., PAN N.H., WANG F.F., YANG Y.Y., LUO H.P. Source apportionment of risk elements in farmland soil of Wuwei, China: Comparison of three receptor models. J Clean Prod, 237, 117792, 2019.

11. BURGES A., EPELDE L., GARBISU C. Impact of repeated single-metal and multi-metal pollution events on soil quality. Chemosphere, 120, 8, 2015.

12. ZAKIR H.M., AYSHA M.I.J., MALLICK S., SHARMIN S., QUADIR Q.F., HOSSAIN M.A. risk elements and Major Nutrients Accumulation Pattern in Spinach Grown in Farm and Industrial Contaminated Soils and Health Risk Assessment. Arch Agric Environ Sci, 3 (1), 95, 2018.

13. ZHANG P.Y., QIN C.Z., HONG X., KANG G.H., QIN M.Z., YANG D., PANG B., LI Y.Y., HE J.J., DICK R.P. Risk assessment and source analysis of soil risk elements pollution from lower reaches of Yellow River irrigation in China. Sci Total Environ, 633, 1136, 2018.

14. CHEN Y.X., JIANG X.S., WANG Y., ZHUANG D.F. Spatial characteristics of risk elements pollution and the potential ecological risk of a typical mining area: A case study in China. Process Saf Environ, 113, 204, 2018.

15. GANUGAPENTA S., NADIMIKERI J., CHINNAPOLLA S.R.R.B., BALLARI L., MADIGA R., K N., TELLA L.P. 
Assessment of risk elements pollution from the sediment of Tupilipalem Coast, southeast coast of India. Int J Sediment Res, 33 (3), 294, 2018.

16. HU J.J., LIN B.J., YUAN M.Y., LAO Z.L., WU K.M., ZENG Y.Y., LIANG Z.H., LI H.R., LI Y.L., ZHU D.; et al. Trace metal pollution and ecological risk assessment in agricultural soil in Dexing $\mathrm{Pb} / \mathrm{Zn}$ mining area, China. Environ Geochem Hlth, 41 (2), 967, 2019.

17. KESHAV KRISHNA A., RAMA MOHAN K. Distribution, correlation, ecological and health risk assessment of risk elements contamination in surface soils around an industrial area, Hyderabad, India. Environ Earth Sci, 75 (5), 411, 2016.

18. ADIMALLA N., WANG H. Distribution, contamination, and health risk assessment of risk elements in surface soils from northern Telangana, India. Arab J Geosci, 11 (21), 1, 2018.

19. CHEN H.Y., TENG Y.G., LU S.J., WANG Y.Y., WANG J.S. Contamination features and health risk of soil risk elements in China. Sci Total Environ, 512-513, 143, 2015.

20. MEHR M.R., KESHAVARZI B., MOORE F., SHARIFI R., LAHIJANZADEH A., KERMANI M. Distribution, source identification and health risk assessment of soil risk elements in urban areas of Isfahan province, Iran. J Afr Earth Sci, 132, 16, 2017.

21. HUANG Y., CHEN Q.Q., DENG M.H., JAPENGA J., LI T.Q., YANG X.E., HE Z.L. risk elements pollution and health risk assessment of agricultural soils in a typical peri-urban area in southeast China. J Environ Manage, 207, 159, 2018.

22. OKEREKE C.J., AMADI P.U. Accumulation and risk assessment of risk elements contents in school playgrounds in Port Harcourt Metropolis, Rivers State, Nigeria. Journal of Chemical Health \& Safety, 24 (5), 11, 2017.

23. SHEN F., LIAO R.M., ALI A., MAHAR A., GUO D., LI R.H., SUN X.N., AWASTHI M.K., WANG Q., ZHANG Z.Q. Spatial distribution and risk assessment of risk elements in soil near a $\mathrm{Pb} / \mathrm{Zn}$ smelter in Feng County, China. Ecotox Environ Safe, 139, 254, 2017.

24. GABARRÓN M., FAZ A., ACOSTA J.A. Effect of different industrial activities on risk elements concentrations and chemical distribution in topsoil and road dust. Environ Earth Sci, 76 (3), 129, 2017.

25. BING H.J., ZHOU J., WU Y.H., WANG X.X., SUN H.Y., LI R. Current state, sources, and potential risk of risk elements in sediments of Three Gorges Reservoir, China. Environ Pollut, 214, 485, 2016.

26. JIN Y.L., O'CONNOR D., OK Y.S., TSANG D.C.W., LIU A., HOU D.Y. Assessment of sources of risk elements in soil and dust at children's playgrounds in Beijing using GIS and multivariate statistical analysis. Environ Int, 124, 320, 2019.

27. PENG J. risk elements content in irrigation farmland soil based on ecological civilization construction. Ekoloji, 28 (108), 1449, 2019.

28. DING Q., CHENG G., WANG Y., ZHUANG D.F. Effects of natural factors on the spatial distribution of risk elements in soils surrounding mining regions. Sci Total Environ, 578, 577, 2017.

29. XIE Z.L., JIANG Y.H., ZHANG H.Z., WANG D., QI S.H., DU Z.B., ZHANG H. Assessing risk elements contamination and ecological risk in Poyang Lake area, China. Environ Earth Sci, 75 (7), 549, 2016.

30. WANG C., YANG Z.F., ZHONG C., JI J.F. Temporal - spatial variation and source apportionment of soil risk elements in the representative river - alluviation depositional system. Environ Pollut, 216, 18, 2016.

31. YUSWIR N.S., PRAVEENA S.M., ARIS A.Z., ISMAIL S.N.S., HASHIM Z. Health risk assessment of risk elements in urban surface soil (Klang District, Malaysia). Bull Environ Contam Toxicol, 95 (1), 80, 2015.

32. TEPANOSYAN G., MAGHAKYAN N., SAHAKYAN L., SAGHATELYAN A. risk elements pollution levels and children health risk assessment of Yerevan kindergartens soils. Ecotox Environ Safe, 142, 257, 2017.

33. WANG B.B., LIN C.Y., ZHANG X., DUAN X.L., XU D.Q. A soil ingestion pilot study for teenage children in China. Chemosphere, 202, 40, 2018.

34. KIM K., KABIR E., KABIR S. A review on the human health impact of airborne particulate matter. Environ Int, 74, 136, 2015.

35. LI X.P., LIU B., ZHANG Y., WANG J.W., ULLAH H., ZHOU M., PENG L.Y., HE A., ZHANG X., YAN X.Y.; et al. Spatial distributions, sources, potential risks of multi-trace metal/metalloids in street dusts from Barbican Downtown embracing by Xi'an Ancient City Wall (NW, China). Int J Env Res Pub He, 16 (16), 2992, 2019.

36. DU H.X., ZHANG J., WANG L., BAI X. The content and contamination characteristic of risk elements in road Greenbelt soil. Applied Mechanics and Materials, 522524, 758-762, 2014.

37. LI X.P., LIU B., ZHANG Y., WANG J.W., ULLAH H., ZHOU M., PENG L.Y., HE A., ZHANG X., YAN X.Y.; et al. Spatial distributions, sources, potential risks of multi-trace metal/metalloids in street dusts from Barbican Downtown embracing by Xi'an ancient city wall (NW, China). Int. J. Environ. Res. Public Health, 16 (16), 2992, 2019.

38. WANG L.J., ZHANG P.Q., WANG L., ZHANG W.J., SHI X.M., LU X.W., LI X.P., LI X.Y. Polycyclic aromatic hydrocarbons in urban soil in the semi-arid city of Xi'an, northwest China: composition, distribution, sources, and relationships with soil properties. Arch Environ Con Tox, 75 (3), 351, 2018

39. GUO B., SU Y., PEI L., WANG X.F., ZHANG B., ZHANG D.M., WANG X.X. Ecological risk evaluation and source apportionment of risk elements in park playgrounds: a case study in Xi'an, Shaanxi Province, a northwest city of China. Environ Sci Pollut R, (1), 2020.

40. WEI B.G., YANG L.S. A review of risk elements contaminations in urban soils, urban road dusts and agricultural soils from China. Microchem J, 94 (2), 99, 2010.

41. CHEN X.D., LU X.W., LI L.Y., YANG G. Spatial distribution and contamination assessment of risk elements in urban topsoil from inside the Xi'an second ringroad, NW China. Environ Earth Sci, 68 (7), 1979, 2013.

42. CAO Z.Z., YANG Y.H., LU J.L., ZHANG C.X. Atmospheric particle characterization, distribution, and deposition in Xi'an, Shaanxi Province, Central China. Environ Pollut, 159 (2), 577, 2011.

43. DAI L.J., WANG L.Q., LI L.F., LIANG T., ZHANG Y.Y., MA C.X., XING B.S. Multivariate geostatistical analysis and source identification of risk elements in the sediment of Poyang Lake in China. Sci Total Environ, 621, 1433, 2018.

44. WANG Q., LU X.W., PAN H.Y. Analysis of risk elements in the re-suspended road dusts from different functional areas in Xi'an, China. Environ Sci Pollut R, 23 (19), 19838, 2016. 
45. PAN H.Y., LU X.W., LEI K. A comprehensive analysis of risk elements in urban road dust of Xi'an, China: contamination, source apportionment and spatial distribution. Sci Total Environ, 609, 1361, 2017.

46. CHEN H., LU X.W. Origin and distribution of trace elements in the campus dust of Xi'an, China. Toxicological \& Environmental Chemistry, 101 (1-2), 75, 2019.

47. SHAO T.J., PAN L.H., CHEN Z.Q., WANG R.Y., LI W.J., QIN Q., HE Y.R. Content of risk elements in the dust of leisure squares and its health risk assessment - A case study of Yanta District in Xi'an. Int J Env Res Pub He, 15 (3), 394, 2018.

48. XU Z.Q., NI S.J., TUO X.G., ZHANG C.J. Calculation of risk elements' toxicity coefficient in the evaluation of potential ecological risk index. Environ Sci Technol, 2 (8), $31,2008$.

49. LU X.W., ZHANG X.L., LI L.Y., CHEN H. Assessment of metals pollution and health risk in dust from nursery schools in Xi'an, China. Environ Res, 128, 27, 2014.

50. YANG Y., ZHOU Z.C., BAI Y.Y., CAI Y.M., CHEN W.P. Risk assessment of risk elements pollution in sediments of the Fenghe River by the Fuzzy Synthetic evaluation model and multivariate statistical methods. Pedosphere, 26 (3), 326, 2016.

51. WANG S.S., ZHAO Z.L., XU Y.Q., LI X.L. Mathematical analysis of urban land use change in Xi'an city wall area by using parcel-level data. Science China Technological Sciences, 62 (4), 687, 2019.

52. WANG Y.J., LIU K.W. Evolution of urban socio-spatial structure in modern times in Xi'an, China. SustainabilityBasel, 9 (11), 1935, 2017.

53. YANG L., ZHANG H.D., CHEN L.D. Identification on threshold and efficiency of rainfall replenishment to soil water in semi-arid loess hilly areas. Science China Earth Science, 61 (3), 292, 2018.

54. GUO B., WANG X.X., ZHANG D.H., PEI L., ZHANG D.M., WANG X.F. A land use regression Application into simulating spatial distribution characteristics of particulate matter (PM2.5) concentration in city of Xi'an, china. Pol J Environ Stud, 29 (6), 1, 2020.

55. SUN L.Q., SUN C.Y., LIU F., BAO X.M. Health risk assessment of oral bioaccessibility of risk elements in soil from coalfield in Huaibei City, China. Human and Ecological Risk Assessment: An International Journal, 25 (8), 2045, 2019

56. CAI L.M., WANG Q.S., LUO J., CHEN L.G., ZHU R.L., WANG S., TANG C.H. risk elements contamination and health risk assessment for children near a large $\mathrm{Cu}$-smelter in central China. Sci Total Environ, 650, 725, 2019.

57. TANG L., DENG S.H., Di Tan, LONG J.M., LEI M. risk elements distribution, translocation, and human health risk assessment in the soil-rice system around Dongting Lake area, China. Environ Sci Pollut R, 26 (17), 17655, 2019.

58. ZHANG Z.Y., LI J.Y., MAMAT Z., QINGFU Y. Sources identification and pollution evaluation of risk elements in the surface sediments of Bortala River, Northwest China. Ecotox Environ Safe, 126, 94, 2016

59. CNEMC. The background values of elements in Chinese soils, Environmental Science Press of China: Beijing, 15, 1990

60. HAKANSON L. An ecological risk index for aquatic pollution control: a sediment ecological approach. Water Res, 14 (8), 975, 1980.

61. TOMLINSON D.L., WILSON J.G., HARRIS C.R., JEFFREY D.W. Problems in the assessment of heavymetal levels in estuaries and the formation of a pollution index. Helgoländer Meeresuntersuchungen, 33 (1), 566, 1980.

62. LIU D.X., MA J.H., SUN Y.L., LI Y.M. Spatial distribution of soil magnetic susceptibility and correlation with risk elements pollution in Kaifeng City, China. Catena, 136, 53, 2016.

63. QIAO P.W., LEI M., YANG S.C., YANG J., GUO G.H., ZHOU X.Y. Comparing ordinary kriging and inverse distance weighting for soil as pollution in Beijing. Environ Sci Pollut R, 25 (16), 15597, 2018.

64. BENHADDYA M.L., BOUKHELKHAL A., HALIS Y., HADJEL M. Human Health Risks Associated with Metals from Urban Soil and Road Dust in an Oilfield Area of Southeastern Algeria. Arch Environ Contam Toxicol, 70 (3), 556, 2016.

65. LI Z.Y., MA Z.W., KUIJP T.J.V.D., YUAN Z.W., HUANG L. A review of soil risk elements pollution from mines in China: pollution and health risk assessment. Sci Total Environ, 468-469, 843, 2014.

66. USEPA Risk Assessment Guidance for Superfund. Human Health Evaluation Manual, (Part A). Office of Emergency and Remedial Response, 1, 1989.

67. USEPA Supplemental guidance for developing soil screening levels for superfund sites. Peer Review Draft, OSWER, 9355, 4, 2001.

68. WANG L.J., LU X.W., REN C.H., LI X.X., CHEN C.C. Contamination assessment and health risk of risk elements in dust from Changqing industrial park of Baoji, NW China. Environ Earth Sci, 71 (5), 2095, 2014.

69. PAN H.Y., LU X.W., LEI K. A comprehensive analysis of risk elements in urban road dust of Xi'an, China: Contamination, source apportionment and spatial distribution. Sci Total Environ, 609, 1361, 2017.

70. ZHANG S.W., WANG L.J., ZHANG W.J., WANG L., SHI X.M., LU X.W., LI X.P. Pollution assessment and source apportionment of trace metals in urban topsoil of Xi'an city in northwest China. Arch Environ Con Tox, 77 (4), 575,2019

71. LIANG J., FENG C.T., ZENG G.M., GAO X., ZHONG M.Z., LI X.D., LI X., HE X.Y., FANG Y.L. Spatial distribution and source identification of risk elements insurface soils in a typical coal mine city, Lianyuan, China. Environ Pollut, 225, 681, 2017.

72. GUAN Q.Y., WANG F.F., XU C.Q., PAN N.H., LIN J.K., ZHAO R., YANG Y.Y., LUO H.P. Source apportionment of risk elements in agricultural soil based on PMF: A case study in Hexi Corridor, northwest China. Chemosphere, 193, 189, 2017.

73. WANG B., XIA D.S., YU Y., CHEN H., JIA J. Source apportionment of soil-contamination in Baotou City (North China) based on a combined magnetic and geochemical approach. Sci Total Environ, 642, 95, 2018.

74. LV J.S., LIU Y., ZHANG Z.L., DAI J.R. Factorial kriging and stepwise regression approach to identify environmental factors influencing spatial multi-scale variability of risk elements in soils. J Hazard Mater, 261, 387, 2013.

75. SUN L., CAREY M., YANG L., CHEN L.D., LI S.J., ZHAO F.K., ZHU Y.G., MEHARG C., MEHARG A.A. Source Identification of Trace Elements in Peri-urban Soils in Eastern China. Expos Health, 11 (3), 195, 2019.

76. LI X.P., FENG L.N. Spatial distribution of hazardous elements in urban topsoils surrounding Xi'an industrial areas, (NW, China): Controlling factors and contamination assessments. J Hazard Mater, 174 (1-3), 662, 2010.

77. YAYLAL1-ABANUZ G. Application of multivariate statistics in the source identification of heavy-metal 
pollution in roadside soils of Bursa, Turkey. Arab J Geosci, 12 (12), 382, 2019.

78. CHEN X., XIA X.H., ZHAO Y., ZHANG P. risk elements concentrations in roadside soils and correlation with urban traffic in Beijing, China. J Hazard Mater, 181 (1-3), 640, 2010.

79. LI S.J., YANG L., CHEN L.D., ZHAO F.K., SUN L. Spatial distribution of risk elements concentrations in periurban soils in eastern China. Environ Sci Pollut Res Int, 26 (2), 1615, 2019.

80. YANG Z.P., LU W.X., LONG Y.Q., HUABAO X., YANG Q.C. Assessment of risk elements contamination in urban topsoil from Changchun City, China. J Geochem Explor, 108 (1), 27, 2011.

81. CHEN T., CHANG Q.R., LIU J., CLEVERS J.G.P.W., KOOISTRA L. Identification of soil risk elements sources and improvement in spatial mapping based on soil spectral information: A case study in northwest China. Sci Total Environ, 565, 155, 2016.

82. LIU R.Q., BAO K.S., YAO S.C., YANG F.Y., WANG X.L. Ecological risk assessment and distribution of potentially harmful trace elements in lake sediments of Songnen Plain, NE China. Ecotoxicol. Environ. Saf., 163, 117, 2018.

83. LU X.W., WANG L.J., LI L.Y., LEI K., HUANG L., KANG D. Multivariate statistical analysis of risk elements in street dust of Baoji, NW China. J Hazard Mater, 173 (13), 744, 2010.

84. LIU P.P., REN H.R., XU H.M., LEI Y.L., SHEN Z.X. Assessment of risk elements characteristics and health risks associated with PM2.5 in Xi'an, the largest city in northwestern China. Air Quality, Atmosphere \& Health, 11 (9), 1037, 2018. 
